\title{
LEGENDINĖS RADVILIŠKIO KAUTYNĖS
}

\author{
Srž. mjr. dokt. Alvydas Tamošiūnas \\ Klaipédos universiteto Baltijos regiono istorijos \\ ir archeologijos institutas
}

Anotacija. Straipsnio tekstas išplauke iš daugiau nei dešimtmeti tyrinètos Nepriklausomybès kovu su bermontininkais medžiagos, kuria sudaro knygos, periodika, Lietuvos centrinio valstybinio archyvo fondu dokumentai, kautyniu prie Radviliškio vietos analizè. Remiantis sukaupta informacija buvo skaitomi pranešimai. Vien 2018 metais pranešimai šia tema buvo skaitomi balandžio 19 d. Šiauliu universitete vykusioje jaunųu tyrëju mokslineje konferencijoje Lietuvos valstybès atkūrimo šimtmečiui paminèti ir lapkričio $9 \mathrm{~d}$. Lietuvos karo akademijoje vykusioje tarptautineje mokslineje konferencijoje „Atkurtai Lietuvos kariuomenei 100 metu“. Bütent šiu pranešimu pagrindu gimusiame straipsnyje nagrinèjama kariavusiu pusiu patirtu nuostoliu santykio problematika. Straipsnyje gilinamasi i vadu pateiktus duomenis apie nuostoliu dydį, jie gretinami su priešo patirtais nuostoliais ir matoma, kad Lietuvos kariuomenes kai kuriu vienetu vadai klydo proporcija „1 su 3“, vertinant puolančiuju ir besiginančiuju nuostolius Radviliškio atveju klasikinès karinès taktikos požiūriu, tiesiog nepritaikoma. Vis dèlto pergalè prie Radviliškio buvo pasiekta, straipsnyje pateikiamos ir nagrinejjamos priežastys, padejjusios laimèti, nepaisant tam tikrų karo meno logikos prieštaravimų. Reikia atkreipti demesị ir ị tai, kad straipsnyje neanalizuojamos kautynès, o tik vertinamos pavienés aplinkybès, kautyniu statistika ir kontekstas.

Pagrindiniai žodžiai: Nepriklausomybès karai, bermontininkai, Radviliškis, Rusija, Vokietija, Lietuvos valstybingumas, kariavusiu pusiu patirti nuostoliai, nuostoliu santykio analize. 


\section{IVADAS}

$2018 \mathrm{~m}$. Vasario 16-ąją buvo paminètas moderniosios Lietuvos 100-metis. Lygiai prieš 100 metų, $1918 \mathrm{~m}$. vasario $16 \mathrm{~d}$., buvo ịkurta nepriklausoma valstybe $\dot{e}^{1}$, kas leido kartu simboliškai atkurti ir senojoje Lietuvoje (1253-1795 m.) puoselètas valstybingumo tradicijas ir užtikrinti jų tęstinumą. Lietuvos Respublikos Seimas 2018 m. paskelbè Lietuvos valstybès atkūrimo šimtmečio metais².

Lietuvos kelias ị valstybingumą su visomis valstybei gyvuoti būtinomis institucijomis, jų kūrimas ir stiprinimas, siekiant protingai laviruoti tarp nedraugiškų valstybių spendžiamų žabangų, buvo labai sudètingas ir ilgas, o Vasario 16-oji tapo pradžių pradžios simboliu, viena reikšmingiausių XX a. Lietuvos istorijos datų. Antrasis pasaulinis karas, okupacijos ir pokario rezistencija paliko itin gilų ir ryškų ịspaudą nepriklausomos Lietuvos istorijos puslapiuose, todèl šešèlyje atsidūrè dauguma kitų svarbių 100-mečio datų, kertinių ịvykių, padẻjusių tvirtus pamatus valstybingumui. Tarp deramo dèmesio nesulaukusių i̇vykių pateko ir Nepriklausomybès karas (1918-1920), nuo kurio pradžios taip pat praejo 100 metų $^{3}$.

2019 m. lapkričio 21-22 d. sukanka 100 metų, kai jauna Lietuvos kariuomené pasiekè ịspūdingą pergalę prieš bermontininkus. Nors ši tema gana plačiai nagrinèta Lietuvos istoriografijoje, šiame straipsnyje naujai pažvelgiama í Radviliškio kautynių problematiką, bandant sugretinti ivairius istorijos duomenis, analizuoti meteorologines sąlygas, kuriomis vyko kautynès, atskleisti istoriografijoje esančių faktų tarpusavio prieštaravimus, pateikti kariavusių pusių patirtų nuostolių santykio analizę ir ¡žvalgas.

1918 m. Lietuvos siekis būti nepriklausoma nesutapo su didžiųjų kaimynių planais. Siekị būti modernia ir nepriklausoma valstybe teko beveik trejus metus ginti ginklu, kurị laiką praktiškai vienu metu net trijuose frontuose, 1918-1920 m. ginklus suremti su bolševikais, gen. Liucjano

1 Barkauskas J. Pirmasis nepriklausomos Lietuvos dešimtmetis. Kaunas, 1990, p. 14.

2 LR Seimo 2012-04-26 nutarimas Nr. XI-1996, www.e-seimas.lrs.lt (2018-09-25).

3 Lietuvos karai. Sudarytojas Vitkus, G. Vilnius, 2014. 


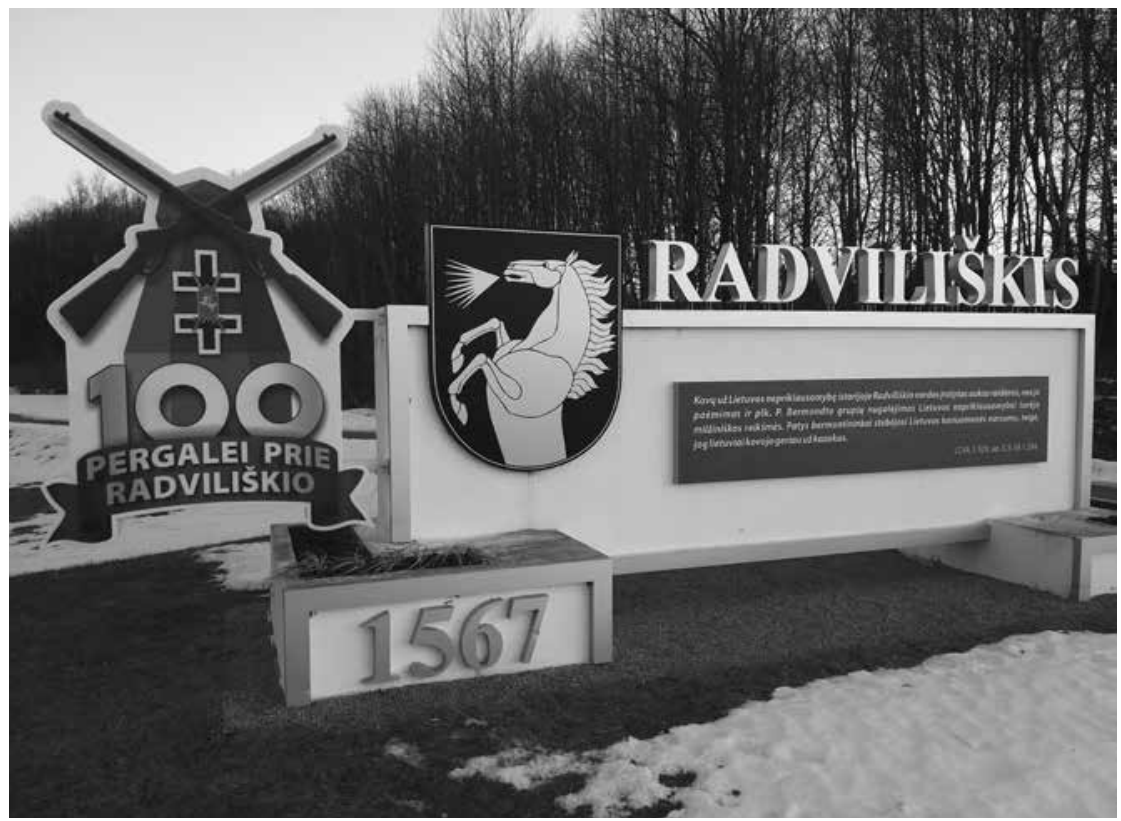

Radviliškio miesto dekoracijos, informuojančios pravažiuojančiuosius apie pergalès Radviliškio mūšyje 100-metị. Autoriaus nuotrauka

Želigovskio (lenk. Lucjan Żeligowski) vadovaujamais pulkais ir bermontininkais. $1919 \mathrm{~m}$. liepos, rugpjūčio ir rugsèjo mẻn. Lietuvos teritorijoje vienu metu buvo visi trys priešininkai - bolševikai, lenkai ir bermontininkai. Pastarieji - keisčiausias darinys, - nors plačiajai visuomenei žinomi kaip de jure vadovaujami Pavelo Bermonto-Avalovo ${ }^{4}$ (rus. Павел Рафалович Бермонт-Авалов, toliau - P. Bermontas), Vakarų savanorių armijos generolo, nuo kurio pavardès ir kilo šio darinio pavadinimas bermontininkai, de facto buvo vadovaujami kaizerinès Vokietijos kariuomenès generolų ${ }^{5}$, užvaldytų revanšistinių nuotaikų po pralaimèto Pirmojo pasaulinio karo. Jie, nors ir praradę Kryžiuočių ordinui priklausiusias

4 Lesčius V. Lietuvos kariuomenė Nepriklausomybės kovose 1918-1920. Vilnius, 2004, p. 194.

5 Skorupskis V. Karas už Lietuvos laisvę 1914-1934. Kaunas, 1934, p. 105. 
žemes ${ }^{6}$, tebepuoselèjo viltis vèl kada nors kolonizuoti Baltijos valstybes ${ }^{7}$ ar bent jau išlaikyti ịtaką regione, rašo $1919 \mathrm{~m}$. birželio $7 \mathrm{~d}$. The New York Times. Vokietija siekè šiame savo istoriniame įtakos regione (minimos Lietuva ir Latvija) išlaikyti provokišką centrą ${ }^{8}$ Kaip taikliai 1938 m. straipsnyje „Trimite“ pažymèjo prof. Izidorius Tamošaitis, „bermontininkai“ buvo ne kas kita, kaip tik vokiečiu aneksionistiniu pastangu tęsèjai ${ }^{9}$.

Vokietijos pretenzijas i Baltijos kraštus galima grịsti Bresto taika, Sovietų Rusijos ir pagrindinių Pirmajame pasauliniame kare dalyvavusių šalių (Vokietijos ir Austrijos-Vengrijos) bei jų sąjungininkių Turkijos ir Bulgarijos $1918 \mathrm{~m}$. kovo $3 \mathrm{~d}$. Brest Litovske (dab. Brestas) pasirašyta sutartimi. Pagal šią sutartị Rusija atsisakè dalies buvusios imperijos teritorijos - Lietuvos, Latvijos, Estijos ir dalies Baltarusijos. Lietuvos Tarybai vasario $16 \mathrm{~d}$. paskelbus nepriklausomybę ir po kiek daugiau nei dviejų mėnesių pasirašius Bresto taikos sutartị, vokiečiai vis dar tebevaldè Lietuvą. Vis dèlto ši sutartis leido Lietuvai formaliai politiškai atsiriboti nuo imperialistines tradicijas perėmusios Sovietų Rusijos. Tai sumažino Rusijos, kaip politinès dominantès, vaidmenị. Vokietija, kita politinè dominantè, ieškodama mūsų krašte naujų ịtakos formų, pasitelkè bermontininkus, kurie patys, jų veiksmai ir deklaruojami tikslai buvo vertinami kaip neaiški geopolitinè anomalija, nedaug ką bendra turinti su realiu pasauliu. Pagrindinè to priežastis buvo tai, kad jų kariuomenès nebuvo egzistuojančios valstybès pajègos, todèl negalejo legitimiai kažkam atstovauti $^{10}$. Kita vertus, juos galima laikyti ir savarankišku politiniu judejimu. Bermontininkų kariuomenę sudarè 1-asis korpusas, dislokuotas Latvijoje, ir 2-asis korpusas, dislokuotas Lietuvoje. Beje, bermontininkai dar buvo vadinami „kolčakais“ arba „kolčakininkais“.

Lietuvoje dislokuotam bermontininkų 2-ajam korpusui vadovavo buvęs žandaras pulkininkas Jevgenijus Virgoličius (rus. Евгений Павлович Вырголич). Jis jau pačioje avantiūros pradžioje nenorejo

\footnotetext{
6 Ten pat, p. 102.

7 Ten pat, p. 103.

8 Strelcovas S. A. Lietuvos nepriklausomybès karas 19018-1920 The New York times puslapiuose. Karo archyvas, t. 32, Vilnius, 2017, p. 42.

9 Timošaitis I. Nepriklausomybès mintys. Trimitas, 1938, Nr. 6 (895), p. 127.

10 Strelcovas S. A. Lietuvos nepriklausomybès karas 19018-1920 The New York times puslapiuose. Karo archyvas, t. 32, p. 41-42.
} 
būti pavaldus P. Bermontui ir sakèsi esąs paties admirolo Aleksandro Kolčako (rus. Александр Васильевич Колчак) paskirtas ir tiesiogiai tik jam pavaldus. Todèl šie atèjūnai Lietuvoje buvo vadinami ne tik bermontininkais, bet ir kolčakininkais ${ }^{11}$. Vokiečių generolas Riudigeris Gustavas Adolfas fon der Goltzas (vok. Rüdiger Graf Gustav Adolf von der Goltz) iš esmès ir buvo pagrindinis visų bermontininkų vadas. Jis nuo 1919 m. rugsejo $5 \mathrm{~d}$. vadovavo kariuomenei net ir iš Lietuvos Joniškio apylinkèse buvusio Satkūnų dvaro, kol ji spalio viduryje pakeitè generolas Wilhelmas Eberhardtas $^{12}$ (vok. Friedrich

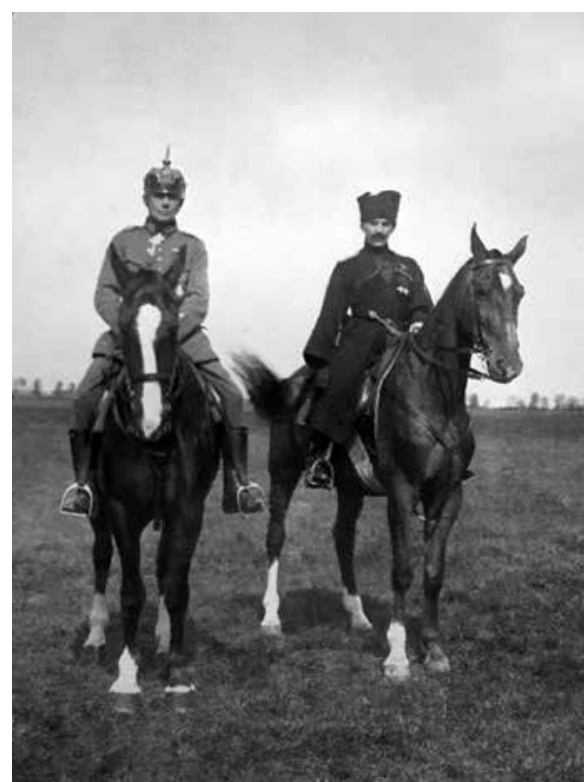

R. Goltzas ir A. Bermontas

Bermontas, A. Mano kova su bolševizmu, Hamburgas, 1925 Wilhelm Magnus Heinrich Walter von Eberhardt). Nors R. Goltzas Vokietijos vyriausybès buvo spaudžiamas grąžinti vokiečių savanorių kariuomenę i̇ Vokietiją, spalio $12 \mathrm{~d}$. visus nepaklususius šiam nurodymui vokiečių karinius vienetus jis perleido P. Bermontui, o pats kurị laiką dar liko jo užnugaryje ir nurodinejo pastarajam, kaip vadovauti. Vokietijos kariuomenès kariams buvo leista išeiti $\mathfrak{i}$ atsargą ir iškart stoti $\mathfrak{i}$ P. Bermonto kariuomenę, tai laikant savotišku Rusijos pilietybės prièmimu ${ }^{13}$. Dar iki formaliai perduodamas vadovavimą, gen. R. Goltzas, suprasdamas, kad nebeturi kuo pateisinti evakuacijos ignoravimo, ryžosi panaudoti kraštutinę priemonę - užkariauti Baltijos šalis - ir įsake pradèti puolimą. Tai suprato ir lietuviai.

11 Čepènas P. Naujųjų laikų Lietuvos istorija, t. 2. Vilnius, 1986, p. 536.

12 Ten pat, p. 541.

13 Birontas A. Bermontininkams Lietuvą užpuolus. Kaunas, 1934, p. 66. 
Jie suvokè, kad derybomis nieko nebepasieks ir reikès reaguoti i jų veiksmus ginklu - teks kovoti ${ }^{14}$.

Pradedamas formuoti frontas su bermontininkais, plk. ltn. Kazimieras Ladiga paskiriamas vadu, o Baisogaloje ịkuriamas štabas: Baisogala tampa prieš bermontininkus veikiančios mūsų kariuomenès nervu centru ${ }^{15}$. Bermontininkai, pradejję plèšikauti ir žudyti, tik paspartino ginkluotą lietuvių reakciją ir nuteikè prieš save vietos gyventojus, todèl netrukus prasidejo aktyvi partizaninė kova. 1920 m. „Trimite“ rašoma: Kova su bermontininkais yra kova ne su kultūringu priešu, ne su priešinga valstybe: tai yra kova su kraugeringomis vagiu, plěšiku gaujomis ${ }^{16}$.

Spalio 9 d. P. Bermonto vadovaujamas 1-asis korpusas pradejo pulti Rygą, o P. Virgoličiaus 2-asis korpusas - Šiaulių-Radviliškio ruože. Tuomet abu korpusai sudarè apie 52000 karių kariuomenę, turèjo 100 patrankų, 600 kulkosvaidžių, 50 minosvaidžių, 27 lèktuvus ir 3 šarvuotuosius traukinius ${ }^{17}$. 2-ajji korpusą sudare 19103 bermontininkai, iš juc 3830 buvo rusai ${ }^{18}$. Nors oficialiai Vokietija buvo uždariusi sieną su Baltijos šalimis ir uždraudusi ginklų ir amunicijos judejimą, faktai kalba ką kita. Pvz., spalio 13-14, 17 ir 19-20 d. iš Vokietijos per Šiaulius Latvijos link riedejo traukiniai, vagonuose gabenantys uniformas, lèktuvus, šovinius ir sviedinius. Maža to, buvo vežami ir kariai. Vien tik spalio $31 \mathrm{~d}$. per Prūsiją i Lietuvą atvyko Gerhardo Rosbacho (vok. Gerhard Roßbach) savanorių korpusas - 1500 karių $^{19}$. Nors padetis dèl politinės padeties buvo komplikuota, bermontininkų kariuomenè ir toliau didejo, o jos karine galia gana sparčiai augo. P. Virgoličiaus 2-asis korpusas prie Radviliškio buvo sutelkęs Šiaulių brigadą, Karlo Diebitšo (vok. Karl Heinrich von Diebitsch) savanorių korpusą, kuris lapkričio $15 \mathrm{~d}$. vis dèlto pasitrauke i Vokietiją, Vokiečių legioną ir aviacijos dalinị. Čia taip pat buvo sukauptos didelès šaudmenų, sviedinių, bombų, ginklų, aprangos, ryšių ir ịvairių lo-

14 Ališauskas K. Lietuvos kariuomenė (Istorinè apžvalga), Karas su bermontininkais. Karys, 1957, lapkritis, p. 284.

15 Trimitas, 1928, Nr. 43 (412), p. 1394.

16 Trimitas, 1920, Nr. 11, p. 26.

17 Lesčius V. Lietuvos kariuomenè Nepriklausomybės kovose 1918-1920, p. 205.

18 Ten pat, p. 200.

19 Čepènas P. Naujųų laikų Lietuvos istorija, t. 2, p. 549. 
gistikos priemonių atsargos ${ }^{20}$. Lietuvos, neturinčios savo karo pramonès ir pakankamai lèšu, prastai ginkluota ir aprūpinta kariuomene kariavo su kur kas galingesniais priešais ir apgynė šalies nepriklausomybę.

\section{I}

Reikia atkreipti dèmesị ir ị tai, kad straipsnyje neanalizuojamos pačios kautynès, o vertinamos jų aplinkybès, statistika ir kontekstas. Kovų su bermontininkais - Nepriklausomybès karų etapą - išsamiai nagrinejjo istorikai Kazys Ališauskas ${ }^{21}$, Vytautas Lesčius ${ }^{22}$ ir Vytautas Steponaitis ${ }^{23}$, 1-ojo pèstininkų pulko Lietuvos didžiojo kunigaikščio Gedimino ${ }^{24}$ ir 2-ojo Lietuvos didžiojo kunigaikščio Algirdo ${ }^{25}$ pesstininkų pulkų istorijos kontekste kautynes - Gintautas Surgailis. Daugelis kitų istorikų, autorių kolektyvų, kovų liudininkų, dalyvių ir amžininkų apie kautynes rašo memuarų, atsiminimų stiliumi (Vladas Skorupskis ${ }^{26}$, Adolfas Birontas ${ }^{27}$, Jonas Petruitis ${ }^{28}$, Jonas Variakojis ${ }^{29}$, Antanas Šukys ${ }^{30}$, Vytautas Landsbergis-Žemkalnis ${ }^{31}$ ). Bet kaip pagrindinị šio fronto ịvykį - jo lūži - visi amžininkai ir istorikai sutartinai pristato kautynes, vykusias Radviliškyje 1919 m. lapkričio 21-22 d.

Lietuvos kariuomenès pergalè prieš bermontininkus, pasiekta kautynèse prie Radviliškio, paliko ilgalaikị isspūdị amžininkams ir sulaukè didelio rezonanso. Rezerve buvusio 1-ojo pėstininkų pulko vadas V. Sko-

\footnotetext{
20 Ten pat, p. 550.

21 Ališauskas K. Kovos dèl Lietuvos nepriklausomybės 1918-1920, t. 1. Čikaga, 1972.

22 Lesčius V. Lietuvos kariuomenė Nepriklausomybės kovose 1918-1920. Vilnius, 2004.

23 Steponaitis V. Bermontininkai Lietuvoje. Mūsų žinynas, Nr. 1 ir Nr. 2, Kaunas, 1921.

24 Surgailis G. Pirmasis pėstininkų Didžiojo Lietuvos kunigaikščio Gedimino pulkas. Vilnius, 2011.

25 Surgailis G. Antrasis Lietuvos didžiojo kunigaikščio Algirdo pėstininkų pulkas. Vilnius, 2014.

26 Skorupskis V. Karas už Lietuvos laisvę 1914-1934. Kaunas, 1934.

27 Birontas A. Bermontininkams Lietuvą užpuolus. Kaunas, 1934.

28 Petruitis J. Mūsų žygiai. Kaunas, 1935.

29 Variakojis J. 4 pėstininkų Lietuvos karaliaus Mindaugo pulkas. Niujorkas, 1965.

30 Šukys A. Du mediniai ir trys geležiniai kryžiai. Vilnius, 2017.

31 Landsbergis-Žemkalnis V. Iš atminties ekrano. Vilnius, 2009.
} 
rupskis savo atsiminimuose rašo, kad tas mūšis ties Radviliškiu su bermontininkais mūsu Tautai yra labai svarbus, nes tas jaunos mūsu kariuomenès laimèjimas prisidejo prie Lietuvos išgelbejjimo ${ }^{32}$. Savo dienoraštyje teisètyrininkas, profesorius ir universiteto rektorius Mykolas Romeris 1920 m. sausio 4 d. rašè: Svarbiausi veikejjai buvo laisvieji šauliai (aut. past. - kariai savanoriai) ir tiesiogine žmoniu gaivališka reakcija. Bet rezultatas lietuviams buvo nuostabus; apsvaigo jie nuo sékmés, ji ikvèpé jiems tikejima savimi, suteike vilčiu. Todel šios nuotaikos drasino juos dabar atsigręžti $j$ lenkus ir bandyti juos išvyti iš Vilniaus tuo pačiu tiesioginio ginkluoto veiksmo metodu. Tokie balsai vis aštriau ir atkakliau skamba Kaune; pastaruoju metu jie tampa kauniškiu aspiracijų pagrindiniu tonu, leitmotyvu. ${ }^{33}$

Pergalè pareikalavo daug aukų. Gaila, bet né vienas istorikas nekèlè diskusijos ir neanalizavo bendro Lietuvos kariuomenès nuostolio ir nelygino jo santykio su priešo netektimis - kiek žuvo ir buvo sužeista karių šiame fronte ir konkrečiai Radviliškio mūšyje. Istorikas G. Surgailis teigia, kad 1919 m. kovose su rusais bolševikais ir bermontininkais žuvo 530 Lietuvos karių ${ }^{34}$. Atskirai pagal frontus Lietuvos kariuomenès nuostoliai neišskirti. Eugenijaus Ivaškevičiaus sudarytame atlase „Lietuvos karių, partizanų ir šaulių kapai “35 galima suskaičiuoti ir priskirti šių frontų aukoms 37 karių kapus, kai nurodyta, kad čia palaidoti nežinomi kariai, žuvę 1919 m., arba konkretaus kario vardas ir pavardè, bet neparašyta tiksli jo žūties data, tiesiog - 1919 m. Taip pat yra užrašų, kuriuose nurodyti žuvusių karių vardai, pavardès ir žūties datos, liudijančios, kad tai įvyko konflikto su bermontininkais laikotarpiu, pradedant nuo fronto suformavimo, t. y. 1919 m. spalio mèn. ${ }^{36}$, ir baigiant jų pasitraukimu iš Lietuvos 1919 m. gruodžio 15 d. ${ }^{37}$ Tokių karių kapų

\footnotetext{
32 Skorupskis V. Per aukas ir pasišventimą laimèjome. Kaunas, 1933, p. 14.

33 Miknys R. Mykolas Römeris. Dienoraštis 1919 m. birželio 21-oji - 1920 m. kovo 15-oji. Vilnius, 2009, p. 241.

34 Surgailis G. 1919-1920 m. Lietuvos nepriklausomybès karas. Lietuvos karai, p. 197.

35 Ivaškevičius E. Lietuvos karių, partizanų ir šaulių kapai, atlasas, 1919-1940. Vilnius, 2003.

36 Lesčius V. Lietuvos kariuomenè Nepriklausomybės kovose 1918-1920, p. 210.

37 Jankauskas V. Kario kelias. Generolas Kazimieras Ladiga Nepriklausomybès kovose. Vilnius, 2004.
} 
suskaičiuota $117^{38}$, neatsižvelgiant ì palaidojimo vietą, nes jie, nors paprastai laidojami šalia pulko vadovybès dislokacijos vietos, pvz., 1-ojo pèstininkų pulko - Baisogalos ${ }^{39}$, o 2-ojo pėstininkų pulko - Šeduvos kapinèse ${ }^{40}$, kartais arčiau gimtųjų kraštų, palaidoti toli nuo karo veiksmų ir žūties vietų (dažniausia - karininkai). 2-ojo pėstininkų pulko leitenantas Serafimas Oželis ${ }^{41}$, žuvęs Radviliškyje, palaidotas Panevėžio miesto kapinèse ${ }^{42}$, to paties pulko leitenantas Petras Urbakonis ${ }^{43}$, žuvęs prie Radviliškio kapinių, - Rokiškio rajono Panemunio miestelio kapinėse ${ }^{44}$. Be to, pažymètina, kad yra nemažai karių kapų, pažymėtų kariškais kryžiais, visiškai be jokios informacijos. Kartu reikètų skaičiuoti šaulius ir partizanus, kurių šiame fronte žuvo 13. Jų vardinis sąrašas pateiktas 1931 m. 27-ame „Trimito“ numeryje ${ }^{45}$. Sąraše nurodytas kario vardas, pavardè, tiksli mirties data ir preliminarios jos aplinkybès - sušaudytas, nukankintas ar nukautas bermontininkų. Gaila, bet nenurodyta vieta. Kiek patyrè nuostolių bermontininkai, tikslių duomenų istorikai taip pat nepateikia. G. Surgailis teigia, kad bermontininkai kovose su lietuviais neteko apie $300 \mathrm{kariu}^{46}$. V. Skorupskis savo atsiminimuose teigia, kad mūšyje prie Radviliškio bermontininku nuostoliai yra didžiausi ir ju yra nukautu 400 ir daugybe sužeistü ${ }^{47}$, o istorikas V. Lesčius rašo, kad prie Radviliškio žuvo 211 bermontininkų ${ }^{48}$.

38 Ivaškevičius E. Lietuvos karių, partizanų ir šaulių kapai, atlasas, 1919-1940. Vilnius, 2003.

39 Ališauskas K. Kovos dèl Lietuvos nepriklausomybès 1918-1920, t. 1, p. 408.

40 Ten pat, p. 408.

41 Ten pat, p. 402.

42 Ivaškevičius E. Lietuvos karių, partizanų ir šaulių kapai, atlasas, 1919-1940. Vilnius, p. 103.

43 Pyragius J. Kovosiu, kol gyvas. Kaunas, 1993, p. 25.

44 Ivaškevičius E. Lietuvos karių, partizanų ir šaulių kapai, atlasas, 1919-1940, p. 128.

45 Trimitas, 1931, Nr. 27, p. 529.

46 Surgailis G. 1919-1920 m. Lietuvos nepriklausomybès karas. Lietuvos karai, p. 199.

47 Skorupskis V. Per aukas ir pasišventimą laimejome, p. 40.

48 Lesčius V. Lietuvos kariuomenè Nepriklausomybès kovose 1918-1920, p. 226. 


\section{II}

Siekiant tinkamai verifikuoti jau žinomus apie Radviliškio kautynes istoriografinius teiginius, iš pradžių reikètų apžvelgti šaltinių grupes, kurias galima suskirstyti į tarpukario, išeivijos ir po 1990 m. išleistus leidinius. Tarpukario šaltinių grupę sudaro Lietuvos kariuomenès leisti leidiniai, tokie kaip „Karo archyvas“, „Mūsų žinynas“, ’̇ kuriuos daugiausia rašè profesionalūs kariai - karo istorikai, pvz., V. Steponaitis. Taip pat reikia paminèti periodiką, kurią sudarè ne tik šalies ir regiono spauda laikraščiai, žurnalai, bet ir Lietuvos kariuomenès leidiniai - žurnalai „Karys“, „Kardas“, Šaulių sąjungos leistas „Trimitas“. Periodikoje dominavo karių straipsniai, pagrịsti atsiminimais.

Kita šaltinių grupé - išeivijoje leisti leidiniai, pasibaigus Antrajam pasauliniam karui, kuriam einant ì pabaigą dalis Lietuvos inteligentijos, taip pat ir karių, iki sovietų okupacijos pasitraukè iš Lietuvos. Skirtingai nuo tarpukario laikotarpio šaltinių, emigracijoje parengti leidiniai negalejo remtis okupuotoje Lietuvoje likusiais archyvais. Buvo naudojamasi kovose dalyvavusių amžininkų atsiminimais ar išgabentų negausių kariuomenès dokumentų fragmentais.

Trečiajai grupei priskiriami leidiniai, išleisti po $1990 \mathrm{~m}$. Karo istorikai, rengdami straipsnius ar knygas apie kautynes, jau galèjo remtis gausia ir vis dar mažai nagrinèta, bet Lietuvoje, Centriniame valstybès archyve, saugoma medžiaga. Išskirtume V. Lesčiaus monografiją „Lietuvos kariuomenė Nepriklausomybès kovose 1918-1920“, kurioje pateikta nuodugni Radviliškio mūšio analizè. Šią knygą pasirinkome istoriografijos verifikacijai atlikti. Po $1990 \mathrm{~m}$. buvo išleista daug naujų ir perleista nemažai tarpukariu ir išeivijoje spausdintų knygų, periodikos, kur demesio skirta ir šioms kautynèms.

Pasitelkę K. Ališausko, V. Lesčiaus ir V. Steponaičio Radviliškio kautynių analizę, peržiūrèkime ịvykių eigą ir dinamiką. Istoriografijos medžiaga, norint atlikti kuo išsamesnị problematikos tyrimą, buvo tarpusavyje derinama ir koreliuojama. Šie trys leidiniai, naudojami kartu, yra naudingi tyrimui jau vien dèl to, kad padeda susidaryti platesni konteksto vaizdą.

Pirma aptarkime, kodèl pastarieji leidiniai buvo parašyti. $1921 \mathrm{~m}$. išleisto „Mūsų žinyno“ ižangoje pabrèžiama, kad valstybès nepriklausomybès garantas yra stipri kariuomenè, kuri turi būti ne tik gerai ginkluota, 
bet ir remtis savo vertybėmis: Armija negali sèkmingai kautis su priešais, jei stoka tautinio susipratimo, kultūros, mokslo9. Svarbiausia - kad pastarasis leidinys taikomas ne tik kariuomenei, bet ir šalies piliečiams, kurie minimi kaip tiksliné auditorija ${ }^{50}$. Teigiama, kad igytos žinios padès dar geriau pažinti ir ginti Tẻvynę nuo kitų pasikèsinimų i nepriklausomybę. O išeivijoje $1972 \mathrm{~m}$. išleistoje knygoje „Kovos dèl Lietuvos nepriklausomybès 1918-1920“ K. Ališauskas pabrèžia, kad vis dèlto tarpukariu Nepriklausomybės kovų istorija taip ir nebuvo parašyta ${ }^{51}$. Nors kartu pripažista, kad pavienių, fragmentiškų publikacijų istorijos žurnaluose buvo. Kaip savo darbo akstiną K. Ališauskas ịvardijo išeivijos visuomenès domejjimąsi ir tuo metu dar gyvų Nepriklausomybės kovų dalyvių raginimus parašyti ir išleisti atskirą išsamų veikalą apie šias kovas ${ }^{52}$. Reikia paminèti ir tai, kad autorius iškart pripažįsta dèl šaltinių trūkumo knygoje būsiančius netikslumus. V. Lesčius monografijoje „Lietuvos kariuomenė Nepriklausomybès kovose 1918-1920“, išleistoje 2004 m., stebisi, kad šalies istorikai, kariai ir visuomenès atstovai išsamios Nepriklausomybès kovų analizès rengti neskubejjo, nors galejo prieiti prie gausių šaltinių ${ }^{53}$. V. Lesčius išskiria V. Steponaiți, pirmą rimtesnių istorinių Nepriklausomybès kovų tyrimų autorių, nors, kita vertus, priekaištauja jam dèl nenurodytų šaltinių, kuriais šiame darbe remtasi. V. Lesčius įžanginiame žodyje gerai ịvertina ir K. Ališausko darbą, nors pripažista, kad šaltinių stoka neleido argumentuočiau atskleisti tam tikrų kovų epizodų ir atlikti gilesnès analizès ${ }^{54}$. V. Lesčius šią temą vertino kaip tam tikrą nišą ir siekè pateikti skaitytojui kuo išsamesnị visos Lietuvos kariuomenès dalyvavimo Nepriklausomybès kovose vaizdą.

Leidinių autoriai kautynèse prie Radviliškio kariavusių pusių nuostolius pateikia gana skirtingai, dèl to ši tema tampa gana aktuali. V. Steponaitis, aprašydamas kautynes, tiksliai nuostolių beveik nę̧vardija. Jis keliose straipsnio vietose abstrakčiai pamini, kad patyręs daug nuostolių puolantis būrys (batalionas) buvo atmuštas. Netgi akcentuojama, kad

\footnotetext{
49 Pradžios žodis. Mūsų žinynas, Nr. 1. Kaunas, 1921, p. 3.

50 Ten pat, p. 4.

${ }^{51}$ Ališauskas K. Kovos dèl Lietuvos nepriklausomybės 1918-1920, t. 1, p. XIX.

52 Ten pat.

53 Lesčius V. Lietuvos kariuomenè Nepriklausomybès kovose 1918-1920, p. 8.

${ }^{54}$ Ten pat, p. 13.
} 
patirta moralinių nuostolių, ką galima suprasti kaip karių motyvacijos praradimą ${ }^{55}$. Tiesa, autorius ịvardija kelis konkrečius asmenis, kurie buvo sunkiai sužeisti ir vèliau mirè (S. Oželis, Karolis Hofmanas). Kautynių aprašymo pabaigoje V. Steponaitis teigia, kad Lietuvos kariuomenè neteko 10 karių (nukauti), 9 buvo sužeisti, o užimtame Radviliškyje lietuviai rado apie 120 nukautų bermontininkų ${ }^{56}$. Šioje vietoje netgi pabréžiama, kad lietuvių ir vokiečių nuostolių proporcija nepalyginama.

K. Ališauskas savo knygoje jau tiksliau įvardija kautynèse patirtus lietuvių nuostolius, juos išskaidydamas i pulkų batalionų nuostolius. Jis rašo, kad 2-ojo péstininkų pulko 1-asis batalionas puolimo metu patyrè nemažai nuostolių: neteko dviejų vadovavusių karininkų (S. Oželio ir P. Urbakonio) ir 14 kareivių ${ }^{57}$. Autorius taip pat pamini ir 33 sužeistuosius, tarp kurių buvo ir visa bataliono vadovybè. Iš rezervo ị kautynes pasiųstas 1-asis pèstininkų pulkas taip pat patyrè nuostolių: 11 žuvusiųjų ir 30 sužeistųjų ${ }^{58}$. Bermontininkų patirti nuostoliai kautynèse neįvardijami arba nusakomi labai abstrakčiai - kad priešininkas tiesiog patyrè ženklius nuostolius.

V. Lesčius savo monografijoje, remdamasis pirminiais šaltiniais, ịvardija daug konkretesnius kariavusių pusių nuostolius, kuriuos suskirstė pagal pulkus. Jis nurodé, kad 1-asis pèstininkų pulkas kautynėse neteko 11 karių, 30 kareivių buvo sužeisti ${ }^{59}, 2$-asis pėstininkų pulkas prarado 16 karių, 30 buvo sužeisti ${ }^{60}$. V. Lesčius gana tiksliai nurodo ir bermontininkų nuotolius. Jie, kovodami su 1-uoju péstininkų pulku, prarado 11 karių, 30 buvo sužeisti, 24 pateko ị nelaisvę, o kovodami su 2-uoju pėstininkų pulku, neteko 200 karių, 400 buvo sužeisti, 117 paimti ị nelaisvę ${ }^{61}$.

Apibendrinant pateiktus skirtingų laikotarpių šaltinių duomenis galima teigti, kad jie nesutampa, o kai kuriuose jų apskritai nėra. Tiksliausius duomenis pateikia V. Lesčius, remdamasis fronto vado K. Ladigos

\footnotetext{
55 Steponavičius V. Bermontininkai Lietuvoje. Mūsų žinynas, Nr. 2, Kaunas, 1921, p. 55.

56 Ten pat, p. 59.

57 Ališauskas K. Kovos dèl Lietuvos Nepriklausomybès 1918-1920, t. 1. 1972, p. 402.

58 Ten pat, p. 406.

59 Lesčius V. Lietuvos kariuomenè Nepriklausomybès kovose 1918-1920, p. 226.

60 Ten pat, p. 225.

61 Ten pat, 226.
} 


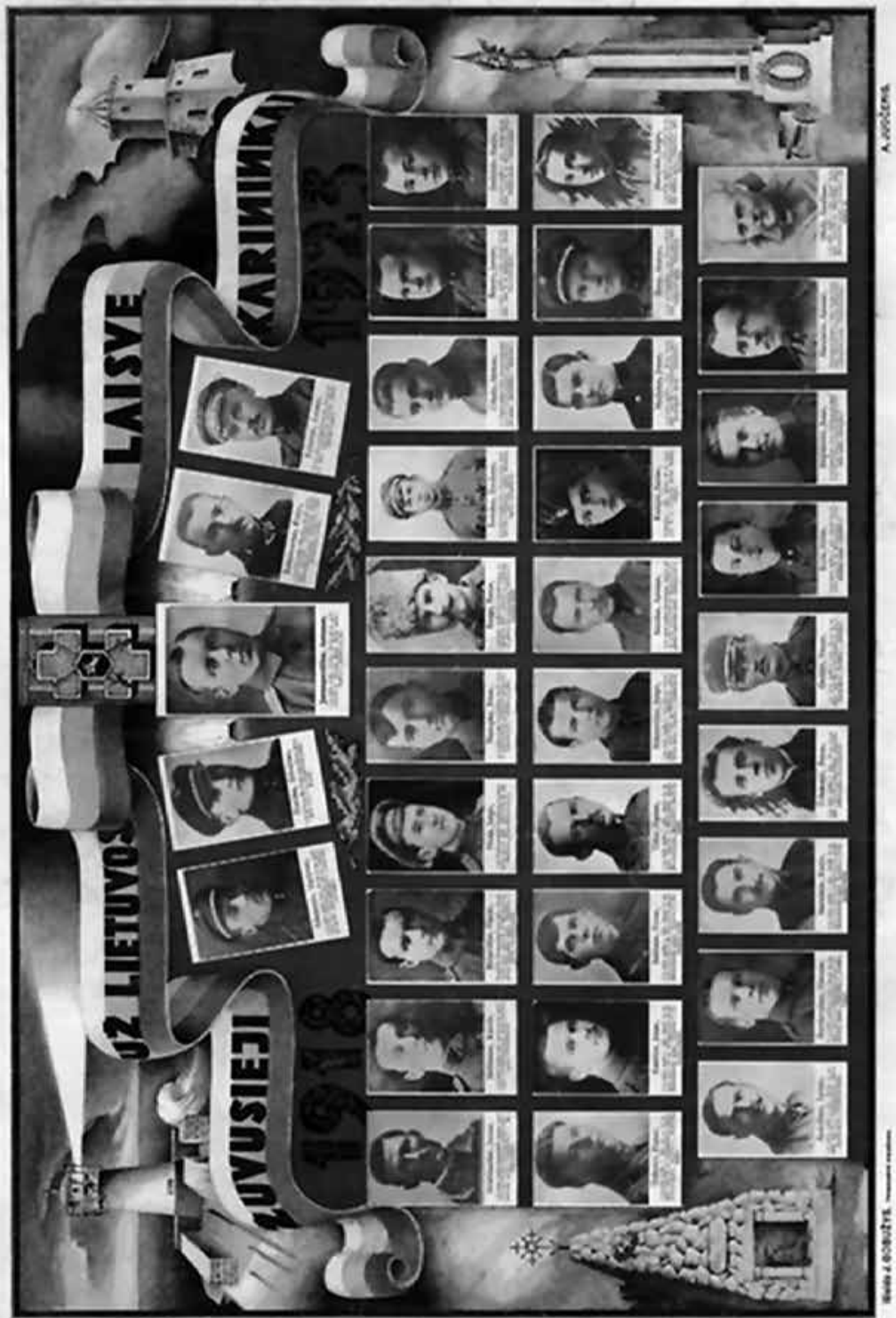

Nepriklausomybės kovose žuvę karininkai. Kretingos muziejus 
pranešimu $^{62}$ Lietuvos kariuomenès vadovybei. Vertètų laikyti V. Lesčiaus monografiją vienu patikimiausių, objektyviausių ir tiksliausių darbų apie kautynes, nors ir antriniu šaltiniu, nes vis dèlto pateikta statistika daugiau kelia klausimų nei duoda atsakymų. Stebėtinai panašus 1-ojo ir 2-ojo péstininkų pulkų ir bermontininkų, kovojusių su 1-uoju pėstininkų pulku, nukautųjų ir sužeistųjų skaičius: atitinkamai 11 ir 30, 16 ir 30, 11 ir 30. O 1-ojo péstininkų pulko patirti nuostoliai sutampa su juo kariavusio priešo nuostoliais - po 11 žuvusiųjų ir 30 sužeistųjų. Ypač pateiktoje statistikoje išsiskiria bermontininkų nuostoliai, patirti susirèmimuose su 2-ojo pėstininkų pulko kariais: nukauta - 200, sužeista - 400, paimta ị nelaisvę - 11763. Susumavus išeina, kad Radviliškio kautynèse puolanti Lietuvos kariuomenè prarado 27 karius (nukauti) ir 60 karių buvo sužeisti, o besiginantys bermontininkai neteko 211 karių (žuvo) ir 430 buvo sužeisti, 141 priešo karys buvo paimtas nelaisvę. Tiesa, Radviliškio savivaldybe், minėdama Radviliškio kautynių 80-metị, sudarè komisiją šiai datai paminèti ir, be įvairios pagalbinès informacijos, nurodè, kad ketveriose rajono kapinèse yra palaidoti 29 Lietuvos kariuomenès kariai, taip pat pateikè jų vardinị sąrašą ${ }^{64}$.

Kautynèse labai nukentėjo bermontininkų Geležinè divizija, Vokiečių legionas, C. Brandžio ir G. Rosbacho rinktinès: žuvo ne tik daug karių, bet ir jų vadai, pavyzdžiui, Vokiečių legiono vadas S. Siewertis ${ }^{65}$. Vadų netekę daliniai iš Lietuvos traukèsi netvarkingai ir padrikai. Nežinia, kiek spéjo bermontininkų po nesèkmingo bandymo gintis, atsitraukti ir pabejgti Šiaulių link, bet, susumavę visus vien tik priešo nuostolius, suskaičiuojame, kad Radviliškio gynyboje dalyvavo mažiausiai 782 bermontininkai.

Pažymėtina, jog V. Skorupskis savo atsiminimuose tvirtina, kad Radviliškị gynė keletas tūkstančių bermontininkų ${ }^{66}$. Interpretuojant pastarają statistiką, kad ir pačius mažiausius skaičius, galima teigti, kad niekas

\footnotetext{
6219191125 Plk. ltn. K. Ladigos pranešimas vyr. kariuomenès vadui, LCVA, f. 929, ap. 3, b. $39,1.283$.

63 Lesčius V. Lietuvos kariuomenė Nepriklausomybès kovose 1918-1920, p. 226.

64 Radviliškio rajono mero potvarkis „Dèl pergalès mūšiuose su bermontininkais 80-mečiui paminèti komisijos sudarymo“, Radviliškis,1997-11-24, Nr. 216.

65 Čepènas P. Naujųų laikų Lietuvos istorija, t. 2, p. 558.

66 Skorupskis V. Per aukas ir pasišventimą laimèjome. Kaunas, 1933, p. 20.
} 
iš nagrinèjamu darbu autoriu nesigilino ị skaičiu santykius, nes klasikinè 1/3 puolančiuju ir besiginančiuju patirtu nuostoliu proporcija Radviliškio kautynems tiesiog nepritaikoma. Autoriai taip pat netyré, ar šie skaičiai tikri, ar tiesiog išgalvoti pulkų vadų. Ypatingas įtarimų šešèlis krenta ant 2-ojo pestininku pulko vado, nes būtent jo paskirtas 1-asis batalionas, turejęs užimti Radviliškị, buvo silpniausias, prasčiausiai parengtas, bet, pagal pateiktą fronto vadui ataskaitos statistiką, padaré daugiausia nuostolių bermontininkams ${ }^{67}$. 2-ojo péstininkų pulko vado nurodytų skaičių „nepatvirtina“ ir bermontininkų kapų skaičius: jų paprasčiausiai nèra arba iki šiol jie neidentifikuoti. Beje, V. Lesčiaus ir V. Glovackio pateikti 2-ojo péstininkų pulko nuostolių duomenys nesutampa, nors V. Lesčius remiasi K. Ladigos , o pastarasis - V. Glovackio ataskaita. V. Lesčius teigia, kad 2-asis pėstininkų pulkas neteko 16 karių (žuvo), dar 30 buvo sužeista, o V. Glovackis vardija savo pulko nuostolius - 13 žuvusiųjų ir 52 sužeisti ${ }^{68}$. Apie tai 2-ojo péstininkų pulko vadas V. Glovackis rašo 2,5 A4 apimties puslapių 2-ojo pėstininkų pulko reliacijoje (mūšio ataskaitoje) „Mūšio nuo 20 iki lapkričio 241919 m.", parengtoje 1919 m. lapkričio 25 d., praejus 2 paroms po kautynių, 2-ojo pèstininkų pulko štabui dar būnant Šeduvoje ${ }^{69}$. Verta paminèti, kad yra dvi skirtingos V. Glovackio parengtos ataskaitos: viena - rašyta ranka, kita - spausdinimo mašinèle. Nuostoliai rašytoje ranka ataskaitoje taip pat skiriasi, ir tai laikytina projektu, matyt, dar tebebuvo renkami ir tikslinami duomenys ${ }^{70}$. Nors abi minètos ataskaitos neabejotinai yra rimtas pirminis informacijos šaltinis, jose pateiktos žinios vargu ar yra patikimos. Dèl akivaizdžiai klaidingų sprendimų V. Glovackis turëjo priežastị juos slèpti, maskuoti, todèl jo ataskaitas reikètų laikyti nepatikimomis.

\footnotetext{
67191911 25, Pulkininkas Glovackis, 2-ojo pėstininkų pulko reliacija, LCVA, f. 929, ap. 3, b. $101,1.7$ ir 8 .

68 Ten pat.

69 Ten pat.

70 Ten pat.
} 


\section{III}

Be abejo, oro sąlygos taip pat turi milžinišką ịtaką bet kokiai karinei operacijai, jos sèkmei, efektyviai ugnies paramai, karių motyvacijai, vienetų manevringumui ir t. t. Bet reikia pripažinti ir tai, kad net ir labai prastos oro sąlygos yra vienodos visoms kariaujančioms pusėms. $1815 \mathrm{~m}$. prieš visiems gerai žinomą Vaterlo (pranc. Waterloo) mūšị prancūzų artileristai skundèsi Prancūzijos imperatoriui ir kariuomenès vadui Napoleonui Bonapartui (pranc. Bonaparte Napoléon) dẻl ribotų pabūklų judèjimo galimybių, nes keliai buvo labai pažliugę. Napoleonas jiems atkirto, kad sąlygos - visiems vienodos, taip pat ir priešui: Manote, ju artileristams yra lengviau?

Verta atskirai pakalbèti ir apie oro sąlygas Radviliškio kautynių metu. Pagrindiniai ivvykiai vyko 1919 m. lapkričio 21, 22 ir 23 d., t. y. penktadiení, šeštadienị ir sekmadienị ${ }^{71}, 48$ metų savaitę. Lapkričio mènesị saule teka 7.58 val., leidžiasi 16.10 val., dienos ilgumas 8.12 val. ${ }^{72}$ Daug kur istoriografijoje, mūšio aprašymuose, teigiama, kad oras ramus buvo vos 1 val. nuo puolimo pradžios ir kad jau apie 4 val. ryto pakilo žvarbus priešpriešinis vejjas ir pradejjo smarkiai snigti. Vẻjas, pučiantis iš vakarų, sniegą nešè ị veidą. Sunkiai slinko mūsų voros pirmyn, nes naktis buvo šalta, pūté smarkus vejjas ir snigo ${ }^{73}$. Oras buvo nekoks, $\mathfrak{i}$ akis pütè vejjas, pradèjo snigti ${ }^{74}$. Oras buvo ramus, bet tarp 4-5 val. pakilo debesys ir pradejo smarkiai snigti, pūtè stiprus véjas, nešantis sniega tiesiai puolantiesiems ị akis ${ }^{75}$.

Po pirmų artilerijos salvių mieste ir dvare kilo gaisras, užsidegè dvaro daržinè. Mūšio pradžioje matomumas dèl didelio gaisro buvo palyginti geras, bet, pradejjus stipriau snigti, labai suprastejo, tai apribojo artilerijos (greičiausiai kulkosvaidžių) paramą ugnimi. Susisiekus su Lietuvos hidrometeorologijos tarnybos prie Aplinkos ministerijos klima-

711919 metų kalendorius, https://www.timeanddate.com/calendar/?year=1919\&country $=90($ Žr. 2018-10-15)

72 Orų prognozè, http://www.oruprognoze.lt/saules-tekejimas/ (Žr. 2018-10-15)

73 Januševičienè A. Savanorių žygdarbis. Radviliškis, 2006, p. 14.

74 Jankauskas V. Kario kelias, generolas Kazimieras Ladiga Nepriklausomybès kovose. Vilnius, 2004, p. 174.

75 Surgailis G. Antrasis Lietuvos didžiojo kunigaikščio Algirdo pėstininkų pulkas. Vilnius, 2014, p. 99. 
tologijos skyriumi dèl 1919 m. lapkričio 21, 22 ir 23 d. buvusių oro sąlygų, 2017-11-20 buvo gautas atsakymas Nr. (10.8)-B8-2599 „Pažyma apie hidrometeorologines sąlygas", parengtas Zinos Kitrienès ir pasirašytas šios tarnybos vedejjo dr. Donato Valiuko. Iš jo paaiškejjo, kad 1915-1922 m. buvo nutrūkę stebejjimai daugumoje meteorologijos stočių: $1919 \mathrm{~m}$. orų duomenis fiksavo tik Vilniaus meteorologijos stotis. Radviliškyje stebejjimai nutrūko 1907 m., Panevėžyje - 1913 m., daugumoje meteorologijos stočių jie atnaujinti ar buvo ịkurtos naujos stotys 1922-1924 m. Šiauliuose meteorologijos stotis ịkurta $1924 \mathrm{~m}$. spalio mèn. Beje, buvo patarta kreiptis i Latvijos meteorologus. Susisiekus paaiškèjo, kad kaimyninëje šalyje situacija buvo praktiškai identiška. Todèl, kad galètume profesionaliai pailiustruoti ir pateikti tikslią informaciją apie Lietuvoje kautynių metu buvusius orus, remsimès Vilniaus meteorologijos stoties duomenimis. Mus dominančio $1919 \mathrm{~m}$. laikotarpio kelios savaitès buvo šaltos: jau spalio $30 \mathrm{~d}$. paros vidutinè oro temperatūra nukrito žemiau $0{ }^{\circ} \mathrm{C}$ ir neigiama išsilaikẻ iki lapkričio $23 \mathrm{~d}$. Žemiausia oro temperatūra buvo nukritusi iki $-22,5^{\circ} \mathrm{C}$ (lapkričio $19 \mathrm{~d}$.), aukščiausia pakilusi iki $+4,3{ }^{\circ} \mathrm{C}$ (lapkričio $25 \mathrm{~d}$.). Vidutinè mènesio oro temperatūra buvo $-5,2^{\circ} \mathrm{C}$, bendras kritulių kiekis - 36,7 mm. $1919 \mathrm{~m}$. matavimai buvo atliekami 3 kartus per parą: 7 val. ryte, 13 val. dieną ir 21 val. vakare. Remiantis Lietuvos hidrometeorologijos tarnybos prie Aplinkos ministerijos Klimatologijos skyriaus pateiktais duomenimis (žr. lentelę) galima teigti, kad kautynių metu per Lietuvos teritoriją iš vakarų i rytus judejjo ciklonas, lapkričio 21 d. virš Radviliškio perejjo šiltas frontas, todèl tą dieną oro temperatūra buvo maždaug $-6 /-1{ }^{\circ} \mathrm{C}$, pasnigo. Praslinkus šiltajam frontui, kitą dieną (lapkričio $22 \mathrm{~d}$.) oro temperatūra pakilo iki maždaug 0-3 laipsnių šilumos, sniego iškrito daug mažiau, palyginti su 21 d., vyravo rūkas, dèl kurio matomumas sumažèjo iki 2-3 km, vejjas buvo nestiprus. Lapkričio 23 d. oro temperatūra toliau kilo iki 3-4 laipsnių šilumos, kritulių nebeliko, rūkas perèjo ị rūkaną ir matomumas padidèjo iki $4-5 \mathrm{~km}$. Kadangi prieš tai buvo iškritę sniego, iki $23 \mathrm{~d}$. jis galejo visas nutirpti, o vietomis išsilaikyti šlapias. Tai tarsi patvirtina įvykių liudininkas ir kovų dalyvis Jonas Pyragius savo atsiminimuose: ...Naktis tyli, be ménesienos. Truputi šąla ir krenta smulkutès snaigès ${ }^{76} . . . S$ alčio, atrodo, nèra. Tik-tik ne atodrèkis.

${ }^{76}$ Pyragius J. Kovosiu, kol gyvas, p. 24. 
Bet valanda pagulejęs imi stingti. ${ }^{77}$

Apibendrinant šią pastraipą galima teigti, kad labai tiksliai nustatyti, kokios oro sąlygos buvo kautynių metu, neįmanoma, nes dauguma meteorologijos stočių, buvusių prie kautynių vietos (Radviliškio, Panevèžio), nutraukè stebejimus, arba tiesiog jų ten apskritai net nebuvo (Šiaulių). Sprendžiant iš Vilniaus meteorologijos stoties užfiksuotų duomenų, orai lapkričio 21, 22 ir 23 d. buvo atšiaurūs. Galima daryti prielaidą, kad, esant šlapiam sniegui, šlapdribai ir vertinant turètą aprangą, abiejų kariavusių pusių kariai, ilgą laiką pabuvę lauke, galèjo būti peršlapę ir sušalę. Tai galejo turèti neigiamą įtaką karių motyvacijai ir nuotaikai. Artilerijos taikinių žvalgyba ir parama ugnimi taip pat buvo sudetingesnè ne tik dèl tiršto snygio ir rūko, bet ir dèl tamsos, nes operacija prasidejo 3 val. nakties, o saule patekejjo tik 8 val. Galima daryti prielaidą, kad bent jau mūšio pradžioje artilerija ir kita parama ugnimi buvo teikiama padrikai, netiksliai dèl riboto matomumo (tamsos, rūko, miglos, lietaus, šlapdribos, snygio) ir vengiant draugiškų pajègų ugnies. Daliai Lietuvos kariuomenès padalinių pavyko patekti į miestą, todèl artilerijos parama buvo paprasčiausiai neịmanoma. Nors Lietuvos karo aviacija gavo įsakymą dalyvauti šio fronto veiksmuose, realaus jos panaudojimo faktų neaptikta. Yra likę tik nurodymai dèl karo aviacijos veiksmų, pvz., kad aeroplanai turi atlikti žvalgyba priešo judejimo daugiausia iš šonu (flangu) Szadovos

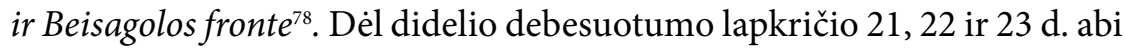
kariaujančios pusès nenaudojo savo karo aviacijos - karo lakūnai negalejjo orientuotis debesuotoje erdveje, matyti taikinių tiek ant žemès, tiek danguje, saugiai nusileisti, nes, neaiškiai matant ar apskritai nematant kilimo (tūpimo) lauko, tai atlikti būtų buvę itin rizikinga. Tai puikiai ịrodo ir iliustruoja 1919 m. spalio 9 d. karo komendanto telefonogramoje Nr. 52 apie Radviliškyje ryte sudužusị vieną bermontininkų lèktuvą pateikta informacija ${ }^{79}$.

77 Ten pat, p. 26.

78 Parèdymas apgynimui Šadova-Baisogala linijos. LCVA, f. 929, ap. 3, b. 1, 1. 271.

7919191009 telefonograma Generalinio štabo viršininkui Nr. 52, LCVA, f. 929, ap. 3, b. $39,1.42$. 


\section{IV}

Žvalgybos duomenys prieš kautynes buvo renkami nenuosekliai, be to, ji nebuvo kokybiška, nors pavienių karių iniciatyva ir daug atlikta reidų í priešo kontroliuojamą teritoriją. Apie prastą žvalgybą ir cirkuliuojančią netikslią informaciją, nepatikimus duomenis užsimenama fronto vado K. Ladigos žinutèje 2-ojo péstininkų pulko vadui Vincui Grigaliūnui-Glovackiui: Tą patikrinau per pulkininka Adamkevičiu ir gavau priešingai jūsu pranešimui ${ }^{80}$. 2-ojo pèstininkų pulko vadas, pradèdamas Radviliškio puolimą, neįvertino jame buvusių bermontininkų pajègų dydžio ir gynybinio potencialo. Atrodo, apie bermontininkus buvo žinoma viskas - kada ir kiek karių išvyko ar atvyko ir kt. Šiuos duomenis teikè partizanai, vietos gyventojai, vadų giminès ir draugai. Informacija Latvijos ir Lietuvos pasienio regione dalijosi ir latviai ${ }^{81}$. Dauguma Lietuvos kariuomenès karių nekantravo kuo greičiau stoti $\mathfrak{i}$ atvirą kovą su bermontininkais. Deja, buvo ir tokių, kurie tylèjo arba net kalbėjo, kad visi žus, o kartu ir jauna valstybè neteks nepriklausomybès ${ }^{82}$. Jau iš pradžių buvo karių, kurie šokinëjo iš traukinių, vykstančių i bermontininkų frontą, vagonų, t. y. dezertyravo, ir karininkų, kurie skleidè savotišką paniką tarp karių, vienas iš jų buvo ịvardintas - karininkas Gerardas Koscelkaukas (Koscialkauskas) $^{83}$. Bègdavo kariai ir iš dalinio dislokacijos vietos ${ }^{84}$. Viena populiaresnių karių dezertyravimo formų buvo negrị̌imas po atostogų $u^{85}$. Užfiksuota, kad prašoma pakeisti net 1-ojo pesstininkų pulko kapelioną Pranas Garmų, kuris negrižo po atostogų, kapelionu Felicijonu Danesevičiumi (Daniusevičus) ${ }^{86}$. Prasidejjus aktyvesniems veiksmams, savavališskai pasitraukiančiųjų dar padaugèjo. Po bermontininkų artilerijos apšau-

\footnotetext{
${ }^{80}$ Jankauskas V. Kario kelias. Generolas Kazimieras Ladiga Nepriklausomybės kovose, p. 160.

${ }^{81}$ Anušauskas A. Lietuvos žvalgyba 1918-1940. Vilnius, 2014, p. 34.

82 Petruitis J. Mūsų žygiai, p. 163.

${ }_{83}$ Zabulionis N. 1-o pèst. pulko 7 kuopos veiksmai prieš bermontininkus. Karo archyvas, t. 10. Kaunas, 1938, p. 207.

${ }^{84}$ Kuopos vado pareiškimas bataliono vadui. $L C V A$, f. 929, ap. 3, b. 108, 1. 111.

8519191010 L. e. p. kuopos vado raportas Panevėžio bataliono vadui. LCVA, f. 929, ap. 3, b. 108, 1. 100.

${ }^{86} 19191115$ 1-o pèstininkų pulko vado majoro Skorupskio pareiškimas 1-os brigados vadui. $L C V A$, f. 929 , ap. 3, b. $29,1.18$.
} 
dymo pabėgo net V. Glovackio adjutantas Antanas Vaičiūnas ${ }^{87}$. Taip pat rasta žinių, kad bermontininkų naudai šnipinèjo ir lietuvių kariai. Vieną tokių sulaikè Radviliškio karo komendantas karininkas Norkus (vardas nenurodytas). Tai buvo 1-ojo pestininkų pulko 3-iojo eskadrono kareivis Steponas (pavardè nenurodyta). Komendanto pranešime Lietuvos kariuomenès Generalinio štabo viršininkui rašoma, kad šis karys teikdavo visą informaciją priešui, todèl toliau apklausti buvo išsiųstas ị Kauną. Kad šis bermontininkų šnipas buvo jiems vertingas, rodo ir komendantui įteiktas ultimatumas grąžinti areštuotąji iki nurodyto laiko, kitaip jie pradèsią šaudyti nelaisveje laikomus lietuvių karius ${ }^{88}$.

Bermontininkų žvalgyboje dirbo ir civilių, kurie kaip agentai galejo likti be darbo sugriuvus Rusijos imperijai. 1920 m. „Trimite“ pateikta keletas pavyzdžių:

Iš Radviliškio ì Kauna (tebesant bermontininkams apie Šiaulius) eina mūsu traukinys, pilnas kareiviu ir civiliniu žmonių. Tarp jų sèdi jauna graži mergina ir kalbina visus aplink. Kalba visomis kalbomis ir vis kalba nukreipia $i$ tai, kad greitu laiku turi visa atsimainyti pas mus, nes būsianti tikra valdžia, o dabar esanti tik „piemenu valdžia“, nieko negalinti ir neišmananti. Ji prieš geraširdžius, neitariančius mūsų kareivius net stačiai sakèsi, kad ji gyvena Kuršènuose su bermontininkais, važiuoja ị Kèdainius, ị savo „giminę", ir ryt vè grišianti atgal ị Kuršènus. Kiek vèliau Panevėžio ruožu važiuoja plačiabarzdis sentikis ir tas kareivius ir kitus kalbina, vis klausdamas, kaip jie žiūri ị dabartinę Lietuvos valdžia ir tvarką, ir prirodinèja, kad prie rusu buvę geriau gyventi, niekam iš mūsu keleiviu jam neprieštaraujant $t^{89}$.

Priešas žvalgybą vykdè pasitelkdamas ir technines priemones. Radviliškyje vokiečių žvalgybos užduotis atlikdavo ir aviacijos dalinys. Tiesa, lèktuvai buvo naudojami ne tik žvalgybai - jie bermontininkams padejo ir kautynėse su Lietuvos kariuomene ${ }^{90}$, sąveikaujant tiek su šarvuotaisiais traukiniais, tiek su pestininkais. Taip pat reikia atkreipti demesị $\mathfrak{i}$ dar vieną detalę - keistą bermontininkų pasirinktą lèktuvų laikymo ir lauko

\footnotetext{
87 Vincas Grigaliūnas-Glovackis. Generolo atsiminimai. II-III dalis. Atsakingasis redaktorius Surgailis G., Vilnius, 2017, p. 99.

8819191009 Radviliškio karo komendanto karininko Norkaus telefonograma Nr. 191 Generalinio štabo viršininkui. LCVA, f. 929, ap. 3, b. 39, 1. 26.

89 Trimitas, 1920 , Nr. 5, p. 30-31.

90 Čepėnas P. Naujųjų laikų Lietuvos istorija, t. 2, p. 550.
} 
aerodromo vietą, kuri buvo Radviliškio pietryčiuose esančiuose laukuose iš Karčemų gyvenvietės pusès, netoli fronto linijos. Pavienès lietuvių žvalgybos grupès, traukiančios iš Karčemų ị Radviliškį, praeidavo pro laukuose išrikiuotus lèktuvus, akylai saugomus priešo sargybinių, kurie, laimé, patamsyje lietuvius palaikydavo savais ir praleisdavo ${ }^{91}$. Nors, kita vertus, būta ir klaidingai pasmerktų, iš anksto neteisingai apkaltintų karių. Paminètinas atvejis, kai kareivis Petras Kinta, laikytas dezertyru, pats grįžo, pabėgęs iš bermontininkų nelaisvès ${ }^{92}$.

Kaip minèta, dauguma lietuvių veržèsi ì mūšị. Veržèsi ne tik kariai, bet ir gydytojai, net kapelionai. 2-ojo pėstininkų pulko vadui paskambinus ị Šeduvoje buvusią 2-ojo pėstininkų pulko 1-ojo bataliono lauko ligoninę paaiškejjo, kad gydytojo Antano Petraičio nèra, nes jis su šautuvu išèjo i frontą. Tada paprašyta prie telefono pakviesti kapelioną kunigą Povilą Šaulinską, bet buvo pranešta, kad ir jo nèra, nes taip pat išèjęs su šautuvu kartu su gydytoju A. Petraičiu ${ }^{93}$. O 1-asis pėstininkų pulkas veržèsi kovon, motyvuojamas šūkiu: Ko kiti nepadarè, mes padarysime! ${ }^{194}$

Vos pasirodę bermontininkai iš karto nuteikè prieš save praktiškai visas oficialias Lietuvos institucijas. Jie paskelbė, kad Lietuva yra rusų kraštas, įsakè valdžios įstaigose vartoti tik rusų kalbą, niekino Lietuvos simbolius, panaikino okupuotose teritorijose valdžios ir savivaldybès ịstaigas ${ }^{95}$. Pašlijo net ir pačių bermontininkų tarpusavio santykiai, sugedo nuotaika. Dar pačioje bermontininkų avantiūros pradžioje, liepos pabaigoje, kol ịsibrovèliai pamažu keliavo per mūsų šalị ir jų vis daugèjo, jau buvo žinoma, kad jie yra nedisciplinuoti ir ištvirkę ${ }^{96}$. Pažymėtina, kad, bent jau iš pradžių, vokiečių karininkai stengèsi būti mandagūs ir pirmi sveikinosi, gatvèje sutikę Lietuvos kariuomenės karininkus ${ }^{97}$. Lietuvių žvalgybos duomenimis, vienybès tarp bermontininkų nebuvo, tarp vokiečių ir rusų nuolat kildavo konfliktai, pasitaikydavo įvairaus masto

\footnotetext{
91 Landsbergis-Žemkalnis V. Iš atminties ekrano. Vilnius, 2009, p. 166.

9219191108 kuopos vado raportas Panevėžio bat. vadui. LCVA, f. 929, ap. 3, b. 108, 1. 115 .

93 Vincas Grigaliūnas-Glovackis. Generolo atsiminimai. II-III dalis, p. 101.

94 Skorupskis V. Per aukas ir pasišventimą laimejome, p. 22.

95 Čepėnas P. Naujųų laikų Lietuvos istorija, t. 2, p. 537.

96 Birontas A. Bermontininkams Lietuvą užpuolus, p. 152.

97 Ten pat.
} 
nepaklusimo vadovybei atvejų ir net sukilimų. Galima net daryti prielaidą, kad rusų ir vokiečių konstruktyvus bendradarbiavimas tiesiog buvo neįmanomas nuo pat šios kariuomenès sukūrimo pradžios, nes iš principo tai juk buvo Pirmo pasaulinio karo priešininkai, kurie galejo net ir menkiausiam pretekstui esant prisiminti, kas už ką ir su kuo kariavo.

Bermontininkų nuotaikas ir kolektyvo mikroklimatą pirmiausia lèmé vadų tarpusavio santykiai. P. Bermontas nevengẻ konfliktų su vokiečių generolų paskirtu P. Virgoličiumi. P. Bermontas ji vadino žmogumi be principų, suardžiusiu jo santykius su Lietuva ir jos vyriausybe, sukompromitavusiu rusų kariuomenę, nes savo daliniams leido vykdyti žiaurias rekvizicijas ir plèšikauti, nuginkluoti lietuvių komendantūras ir sargybas. P. Bermontas taip pat kaltino P. Virgoličių dangstantis jo vardu ir dedantis vykdant jo nurodymus ${ }^{98}$. Kad P. Bermonto ir P. Virgoličiaus santykiai buvo ganėtinai ịtempti, liudijo ir Mintaujoje apsilankęs Vokietijoje veikusios Vakarų Rusijos vyriausybės formalus vadovas Vasilijus Biskupskis $^{99}$. Apie tai savo atsiminimuose rašè ir bermontininkų karininkas Ivanas Konoplinas - kad konflikto priežastis buvo perdètas P. Virgoličiaus savarankiškumas, kurị neigiamai vertino P. Bermontas ${ }^{100}$. Istorikas Aleksandras Čapenka netgi daro drąsią prielaidą, kad būtent asmeninė P. Bermonto ir P. Virgoličiaus antipatija priverte pastarajj su bermontininku 2-uoju korpusu pasitraukti i pietus, ił Lietuvą ${ }^{101}$. Tarpusavio santykiams turejo ịtakos ir P. Bermonto santykiai su gen. Nikolajumi Judeniču (rus. Никола́й Никола́евич Юде́нич). Situacija puikiai iliustruojama žvalgybos pranešime apie 1919 m. spalio 27-lapkričio 4 d. ịvykius. Čia atsiskleidžia tarpusavio santykiai ir rusų nuotaikos:

Radviliškio rajone labai pablogèjo vokiečiu ir bermontininku santykiai... vokiečiai net nuginkluoja nekurias rusu dalis ir siunčia jas Rygos link... Bermontininku üpas didžiai nupuole, kai jie sužinojo gen. Judeničo isakymą, kuriuo griežtai jis pasmerkè pulk. Bermonto-Avalovo darbuotę, kaipo Rusijos valstybès išgamas, ir šaukia rusu kareivius ir karininkus ša-

98 Čepėnas P. Naujųjų laikų Lietuvos istorija, t. 2, p. 538.

99 Čapenka A. 2-ojo Vakarų savanorių korpuso formavimo istorija ir jo dalyvavimas „bermontiadoje“ Lietuvos teritorijoje 1919 metais. Karo archyvas, t. 25. Vilnius, 2010, p. 128.

100 Ten pat, p. 129.

101 Ten pat. 
Latvių

karikatūra

pasiekus

pergalę prieš

bermontininkus.

Bermontas, A.

Mano kova

su bolševizmu.

Hamburgas,

1925

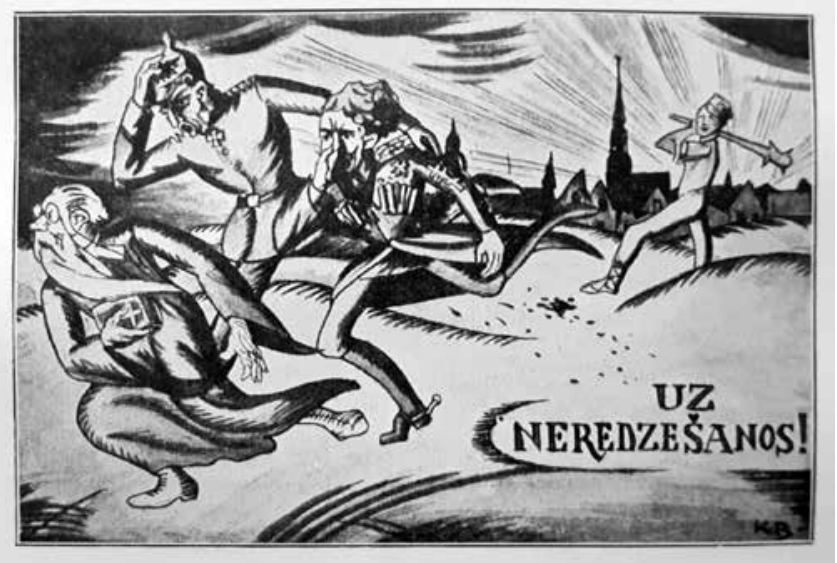

lintis Bermonto bei Virgoličo avantiūrų... Dèl tos tai priežasties Bermonto dalyse kyla nesusipratimu ir nieku büdu jei nenori kovoti su lietuviais ${ }^{102}$.

Savo atsiminimuose įtemptus vokiečiu ir rusų tarpusavio santykius aprašo A. Birontas: Tarp bermontininkų ir vokiečiu dažnai susišaudoma, jog susiginčiję kuopoje vokietis ir rusas griebiasi ginklo ir jog tuoj vieniems ir antriems draugai ateina pagalbon ir ivyksta tikra batalija. A. Birontas taip pat mini pilnus sužeistųjų vežimus, dardančius iš Kuršènų i Šiaulius, nors jokie kovos su lietuviais veiksmai dar nevyko, o ligoninès jau buvo užplūstos sužeistų bermontininkų ${ }^{103}$. Neką geresnè buvo ir vokiečiu situacija: Vokiečiu kariuomeneje nèra jokios drausmés bei tvarkos... Buvo net vienoj daly ekonominio pagrindo sukilimas... Padidinus alga kareiviai vis tik nurimo ${ }^{104}$. Nuotaikas diktavo ir ịvykiai Latvijoje, bermontininkų nesèkmés prie Rygos vare į neviltį bermontininkus Lietuvoje. Tai patvirtina ir istorikas A. Capenka: Latvijoje iš esmés pasikeitusi padètis turèjo įtakos ir kovos veiksmams Lietuvos teritorijoje: E. Virgoličiaus korpuse smarkiai pašlijo drausmè, prasidèjo masinis karių dezertyravimas ${ }^{105}$.

10219191027 -11 04 laikotarpio žinios. Bermontininkų ir vokiečių frontas. LCVA, f. 929, ap. 3, b. $36,1.131$.

${ }^{103}$ Birontas A. Bermontininkams Lietuvą užpuolus, p. 67.

${ }^{104}$ Ten pat.

${ }^{105}$ Čapenka A. 2-ojo Vakarų savanorių korpuso formavimo istorija ir jo dalyvavimas „bermontiadoje“ Lietuvos teritorijoje 1919 metais. Karo archyvas, t. 25, p. 133. 
Apskritai bermontininkai - nei vokiečiai, nei rusai - Lietuvos kariuomenei nesudare kontroliuojamos ir reguliarios kariuomenès ìspūdžio. Jie buvo laikomi plèšikų gaujomis, nes jos alino vietos gyventojus, atiminejjo arba naikino jų turtą, plèšè net Lietuvoje buvusius užsieniečius. Du bermontininkų leitenantai Šiauliuose užpuolè ir apiplèšè Lietuvos kariuomenès instruktorių iš Švedijos plk. Falkę Arnbergerị. Iš jo atemė piniginę, revolverị, laikrodị ir... nosinę $e^{106}$. Plèšè ne tik žmonių ir ịstaigų, bet ir bažnyčių turtą. Užfiksuota, kaip bermontininkas Skuodo bažnyčioje, išsaugotoje per visą Pirmąji pasaulinị karą, sekmadienio pavakare besimeldžiančių žmonių akivaizdoje pradejo nuo didžiojo altoriaus viską mètyti ir trypdamas lankstyti inventorių ${ }^{107}$. Tai, ko negalejo paimti, bermontininkai dažnai tiesiog sudegindavo ${ }^{108}$. Maža to, tarsi nužmogèję îsibrovèliai vietinius mušè, žudè ir žagino. Kaip rašo 1919 m. spalio $8 \mathrm{~d}$. telefonogramoje Lietuvos spaudos biuro pranešimų skyriaus vedèjas (parašas neịskaitomas), p. Arbaliu sodyboje nukové jauna mergaitę, kuri atsisake kolčiakui sviesto duoti. Paupių sodžiuj taip sumušè Digienę, kad ji dèl to ir pasimirè. Ir šiaip randama užmuštų žmoniu, mirties priežastis kurių nežinoma ${ }^{109}$. Keturi padugnès bermontininkai privertė pririštą tèvą stebėti, kaip žagino jo dukrą ${ }^{110}$. Ir visa tai buvo fiksuojama.

Intensyviai dirbo lietuvių ne tik žvalgyba, bet ir kontržvalgyba. Viena pagrindinių kontržvalgybos funkcijų buvo belaisvių ir pabėgèlių tardymas, vadinamoji filtracija. Tuo buvo siekiama ne tik išaiškinti priešo žvalgus, bet ir užverbuoti Lietuvos žvalgybai tinkančius asmenis. Visi belaisviai ir pabègèliai, papuolę lietuviams ị rankas, vienaip ar kitaip pereidavo Žvalgybos skyriaus ar jo punkto patikrą, apklausą. Perbejgèliai iš bermontininkų kariuomenès, norintys pereiti ị N. Judeničo kariuomenę, buvo siunčiami per Rokiškio žvalgų punktą ì Latviją, o rusai, norintys grịžti ị Baltarusiją ir Ukrainą ${ }^{111}$, turèjo pereiti Kauno žvalgybos skyriaus

\footnotetext{
106 Ten pat, p. 153.

107 Žadeikis P. Didžiojo karo užrašai. II dalis. 1917-1918-1919 metai. Klaipèda, 1925, p. 285.

108 Ten pat.

${ }^{109} 19191008$ Lietuvos spaudos biuro vedejo P. Skyriaus telefonograma. LCVA, f. 929, ap. 3, b. 29, 1. 35 .

${ }^{110}$ Eidintas A. Slaptasis lietuvių diplomatas. Vilnius, 1992, p. 157.

111 Anušauskas A. Lietuvos slaptosios tarnybos 1918-1940. Vilnius, 1998, p. 35.
} 
patikrą. Šauliai ir partizanai taip pat svariai prisidèjo prie priešo žvalgų išaiškinimo ir sulaikymo. Dažniausia nuodugniau tikrindavo nepažįstamus vyriškius, ypač tuos, kurie nemokèjo lietuvių kalbos. 1936 m. „Trimite" rašoma, kaip šaulių sulaikomas asmuo:

Lapkričio 7 d. būrio šauliai Julijonas ir Juozas Tamošiūnai atvedè sulaikę nepažistama vyriškį, kuris, norėdamas, kad ji šauliai paleistu, davé jiems 60 markių. Peržvelgiau jo turima dar vokiečiu okupacinès valdžios Juozo Novicko vardu išduota asmens dokumenta... ịtariau ji šnipinèjant bermontininkams. Paklaustas lietuviškai, kur jis einąs, tik galva pakratè nesuprato. Tad ji iškrateme ir radome dideli lenktini peili ir 4613 markiu visai naujais vokiečiu banknotais. Toliau tardomas prisipažino, kad esąs Kubanès kazoku leitenantas Aleksandras Stoše, ...einąs i Šiaulius pas bermontininkus, o kad lietuviai kaunasi su bermontininkais, tai jis nežinąs ir t. t. Surašę protokola, nuvedem ji pas Ukmergès karo komendantą ${ }^{112}$.

Taip pat reikia pažymèti, kad ir po gruodžio $15 \mathrm{~d}$., kai buvo oficialiai paskelbta, kad bermontininkų kariuomenès Lietuvoje nebèra, vis dèlto bermontininkų liko, tik jie buvo suimti ir turejjo belaisvio statusą. „Trimite" rašoma, kad 1920 m. vyko derybos dèl apsikeitimo belaisviais: Mūsu valdžia sutiko pasikeisti su vokiečiais mūsų ir bermontininku belaisviais su salyga, kad vokiečiai atiduos visus savo pavaldinius bermontininkus teis$m^{113}$.

Iki pirmųjų ginkluotų susirèmimų patys bermontininkai Lietuvos kariuomenès karių nevertino ir laikẻ lengvai ịveikiamu priešininku. Dar spalio 16 d. bermontininkai, siekdami sustiprinti Radviliškio apsaugą, iš Rygos fronto perdislokavo C. Brandžio vadovaujamą savanorių rinktinę: Jie žygiavo ị Lietuvq "pamokyti nedékingu ir suįžūlejusių lietuviü. Brandžio rinktinés kariu tarpe nuotaika buvo gera, nes lietuviu kariuomenę laike nepavojinga, bet vis dèlto prisibijojo, kadangi lietuviai nuo senu laiku buvo žinomi kaip nakties meto puolimo dideli specialistai. Brandis, su savo rinktine atžygiavęs į Radviliškį, džiaugèsi čia rasta maisto gausa... ${ }^{114}$

Ne veltui bermontininkai prisibijojo lietuvių veiksmų naktị, nes būtent tamsiu paros metu jie pasiekdavo daugiau nei dieną. V. Skorupskis prisimena: Kai reikèdavo vokiečius pulti diena su silpna technika, tai per

\footnotetext{
112 Trimitas, Nr. 24, 1936, p. 566.

113 Trimitas, Nr. 1, 1920, p. 21.

114 Čepėnas P. Naujujų laikų Lietuvos istorija, t. 2, p. 550.
} 
keleta ataku nieko diena negalèdavome padaryti, tik veikdami paslapčia nakti - laimédavome ${ }^{115}$. O ir patys lietuvių kariai suprato, kad jie yra žymiai efektyvesni tamsiu paros metu, nei puldami dieną atvirame lauke gerai ịsitvirtinusį priešą: Nieko, ateis vakaras, ir naktị mes parodysime, kaip reikia imti pasipriešinimo punktus atakuojant ${ }^{116}$. Dar vienas epizodas: Ir mes, matydami, kad diena nieko negalime padaryti, atejjus nakčiai, ejome i baisia durtuvu atak $q^{117}$. Be to, bermontininkai kariavo svetimoje žemejje, toli nuo savo šeimų ir gimtụjų vietų ir, ko gero, vienintelis jų tikslas buvo išgyventi. Tai buvo desperatiškas bandymas apginti tiesiausią ir greičiausią atsitraukimo kelią iš Baltijos kraštu ị Prūsiją $a^{118}$ - namų link.

\section{V}

1919 m. lapkričio 18 d. Baisogaloje fronto vadas K. Ladiga ịsakyme Nr. 7/s nurodè vienetų vadams pulti bermontininkus visu frontu trimis voromis. V. Skorupskis savo atsiminimuose rašo: Buvo tinkama valanda pulti, be to, gera dvasinè mūsu kariuomenès büklè, todèl ir reikëjo pulti priešą ${ }^{119}$. II voros vadu buvo paskirtas 2-ojo pèstininkų pulko vadas V. Glovackis ${ }^{120}$, turintis 2241 karị $^{121}$. Jo pagrindinè užduotis buvo užimti Šiaulius, pasitelkus tris batalionus: 1-ąji (vadas Jonas Motiejūnas-Valevičius), 2-ajji (vadas Kazys Ramanauskas) ir 3-iajji (vadas Jonas Petruitis) - bei priskirtus vienetus: 2 -ojo husarų eskadrono būrị, 5 geležinkelio sprogdintojus ir 25 išminuotojus. İsakyme fronto vadas nurode viską, išskyrus tikslų operacijos pradžios laiką. Pastarasis nurodytas dviem paromis vèliau ịsakyme Nr. 8/s: ịsakyta puolimą pradèti brèkštant (pradètas 3 val. ryto) ir vadovautis anksčiau išleistame įsakyme nurodytomis

\footnotetext{
115 Skorupskis V. Per aukas ir pasišventimą laimejjome, p. 22.

116 Ten pat, p. 25.

117 Ten pat.

118 Jurgela R. History of the Lithuanian Nation, Constantine, Cultural Institute. Niujorkas, 1948, p. 514-515.

119 Skorupskis V. Per aukas ir pasišventimą laimejome, p. 21.

${ }^{120}$ Rakutis V., Vaičenonis J. Lietuvos didžiojo kunigaikščio Algirdo mechanizuotojo pèstininkų bataliono istorija. Vilnius, 2012, p. 62.

${ }^{121}$ Lesčius V. Lietuvos kariuomenè Nepriklausomybès kovose 1918-1920, p. 223.
} 
puolimo detalėmis. 2-ojo péstininkų pulko vadas V. Glovackis fronto vado sumanymą - užimti Radviliški - ketino nurodyti igyvendinti 1-ajam batalionui, o 2-ajam ir 3-iajam - apeiti („flanguoti“) ji iš šiaurès ir judèti Šiaulių link ${ }^{122}$.

Šioje vietoje pereiname prie problematikos - 2-ojo pėstininkų pulko vado V. Glovackio sprendimai kelia pagrịstų abejonių. Kad ir skiriant užduotis - 1 batalionas (silpniausias) gauna užduotị užimti Radviliškị, 2-asis ir 3-iasis batalionai apeina vietovę ir be didesnio pasipriešinimo, išgirdę apie prasidejjusias Radviliškyje kautynes, sustoja. Batalionai tarpusavyje nesąveikauja, t. y. veikia kiekvienas atskirai. Taigi operacijoje dalyvauja ne vientisas pėstininkų pulkas, o trys batalionai. Pulko vadas, susitelkęs ị Šiaulių užèmimo operaciją, neịvertino Radviliškio faktoriaus. 2-ojo pèstininkų pulko vadas V. Glovackis tikèjosi, kad bermontininkai greitai atsitrauks ir paliks Radviliškị, todèl jị užimti pavedè 1-ajam batalionui, kuriame buvo daug jaunų, praktiškai neapmokytų karių. Šis batalionas, užèmęs miestelị, turèjo žygiuoti geležinkeliu ị Šiaulius ir ten sustoti, o stipresni batalionai - užimti Šiaulius ${ }^{123}$.

Abejonių kelia tai, kad pulko vadas neịvertino arba net nežinojo apie 800 Radviliškyje įsitvirtinusių ir gerai ginkluotų bermontininkų. Jau minèta, kad V. Skorupskis savo atsiminimuose rašo, jog Radviliškio gynyboje buvo keletas tūkstančų priešo kareivių ${ }^{124}$, nors jo paties žvalgai suskaičiavo nuo 800 iki $1000^{125}$. Visą pasirengimo Šiaulių-Radviliškio operacijai eigą - tiek pulko, tiek fronto vado veiksmus - aptariantys šaltiniai visiškai nemini žvalgybos duomenų, todèl nežinia, ar iš viso kautynių išvakarèse buvo atlikta žvalgyba. Nors 2-ojo pėstininkų pulko vadas V. Glovackis buvo žinomas kaip vadas, mėgstantis prieš didesnius pulko veiksmus pasitarti su artimiausiais savo padejejjais - batalionų vadais, bet iš tikrujjų nelinko jų patarimų klausyti - visada spręsdavo pats vienas, savarankiškai ${ }^{126}$.

\footnotetext{
122 Surgailis G. Antrasis Lietuvos didžiojo kunigaikščio Algirdo pėstininkų pulkas, p. 98. ${ }^{123}$ Lesčius V. Lietuvos kariuomenè Nepriklausomybès kovose 1918-1920, p. 223.

${ }^{124}$ Skorupskis V. Per aukas ir pasišventimą laimejome, p. 20.

${ }^{125}$ Baniusevičius A. Lietuvos kariuomenès kautynès su bermontininkais prie Radviliškio. Karo archyvas, t. 13, Vilnius, 1992, p. 144.

126 Ališauskas K. Kovos dèl Lietuvos nepriklausomybès 1918-1920, t. 1, p. 399.
} 
Isakymą paskelbus iki operacijos likus porai dienų, buvo pakankamai laiko tinkamai pasiruošti ir situacijai îvertinti. İdomi detalè - i paskutini pasitarimą prieš mūš pulko vadas nepakvietė savo pavaduotojo ${ }^{127}$. Jame buvo teikiami esminiai pasiūlymai, galintys pakreipti kautyniu eigą kitaip. 3-iojo bataliono vadas J. Petruitis pasitarimo su pulko vadu metu pasiūle Radviliškị užimti patikèti būtent jo batalionui ${ }^{128}$. Vienas iš bataliono vado argumentu buvo tai, kad jis pats ir keli karininkai (Liudas (Liudvikas) Butkevičius, Martynas Jakobsonas) yra radviliškiečiai, tad puikiai pažįsta Radviliški ir jo apylinkes. Bet pulko vadas pasielge kaip visada - nekeite savo sumanymo. Dèl to greičiausiai 1-ojo bataliono vadas Motiejūnas-Valevičius, nepažistantis vietoves, puole Radviliškị iš labiausiai ịvirtintos pusès - pietryčių, o ne iš šiaurès, kur plytèjo atvira vietove ir nebuvo natūralių priedangų, tokių kaip malūnai ${ }^{129}$ ar kapinès akmeninemis sienomis ${ }^{130}$, o prieigos prie jų buvo atviri laukai. Be to, bermontininkai, lietuviams pradejjus puolimą, sutelkè gynybai savo pajegas rytinèje Radviliškio puseje ir paliko praktiškai neapsaugotas vakarinę ir šiaurinę miestelio prieigas. Tai taip pat nebuvo ịvertinta.

Siekiant kuo objektyviau ištirti 2-ojo pesstininkų pulko priimtų sprendimų grandinę, pateikiama subordinacijos eilè - nuo aukščiausiojo iki žemiausiụjų vadų, jų trumpos biografijos ir svarbiausi tarnybos etapai, kurie leidžia susidaryti bendrą nuomonę apie šių vadų kompetenciją.

Fronto vadas K. Ladiga Pirmajji pasaulinį karą praleido fronte - tarnavo Rusijos kariuomenès 18-osios divizijos 70-ojo Riažsko pulko žvalgų daliniuose, kovojusiuose Daugpilio fronte, užsitarnavo kapitono laipsnị, buvo du kartus sužeistas, septynis kartus apdovanotas ịvairiais ordinais $^{131}$.

2-ojo pėstininkų pulko vadas V. Glovackis Pirmajji pasaulinị karą taip pat praleido fronte - tarnavo Rusijos kariuomenès 6-ajame Turkestano šaulių pulke, užsitarnavo kapitono laipsnị. Buvo tris kartus sužeistas, ap-

\footnotetext{
${ }^{127}$ Petruitis J. Mūsų žygiai, p. 165.

${ }^{128}$ Surgailis G. Antrasis Lietuvos didžiojo kunigaikščio Algirdo pėstininkų pulkas, p. 98.

${ }^{129}$ Birontas A. Bermontininkams Lietuvą užpuolus, p. 237.

${ }^{130}$ Rakutis V., Vaičenonis, J. Lietuvos didžiojo kunigaikščio Algirdo mechanizuotojo pèstininkų bataliono istorija, p. 63.

${ }^{131}$ Kavaliauskas V. Lietuvos karžygiai, Vyties Kryžiaus kavalieriai. II tomas, E-J (19181940). Vilnius, 2009, p. 378.
} 
dovanotas 6 ordinais ir aukso Šv. Jurgio (Grigorijaus) kardu ${ }^{132}$.

Iki 2-ojo péstininkų pulko 1-ojo bataliono vadas J. Motiejūnas-Valevičius Pirmajji pasaulinị karą taip pat praleido fronte - tarnavo Rusijos kariuomenès 202-ajame péstininkų pulke, užsitarnavo štabskapitono laipsnị. Buvo du kartus sužeistas ir kartą kontūzytas, apdovanotas trimis ordinais $^{133}$.

2-ojo péstininkų pulko 1-ojo bataliono 1-osios kuopos vadas P. Urbakonis per Pirmaji pasaulinị karą kovojo fronte - tarnavo Rusijos kariuomenès 493-iajame Klinsko pėstininkų pulke, užsitarnavo viršilos laipsnị. Buvo du kartus sužeistas ${ }^{134}$.

2-ojo péstininkų pulko 1-ojo bataliono 3-iosios kuopos būrio vadas S. Oželis 1919 m. kovo mèn. ịstojo ị Karo mokyklą ir sẻkmingai ją bai$\mathrm{gè}^{135}$.

Kaip matome, praktiškai visi paminèti vadai turèjo milžinišką kariavimo patirtị (išskyrus S. Oželį), igytą Pirmajame pasauliniame kare, kovojant su ne bet kuo, o su tais pačiais vokiečiais, kurių dalis véliau tapo bermontininkais. Atkreiptinas demesys, kad tai buvo Rusijos kariuomenès mokykla ir kad dauguma lietuvių aukštesniųjų vadų Rusijos kariuomenejje užsitarnavo tik kapitono laipsnị ir galèjo vadovauti nedideliems kariniams vienetams - nuo kuopos iki bataliono dydžio. Lietuvos kariuomenejje jie praktiškai visi ejo mažiausiai viena pakopa aukštesnes pareigas nei turèta patirtis ir vadovavo didesniems Lietuvos kariuomenès vienetams nei Rusijos kariuomenejje.

Vis dèlto didžiausią atsakomybę dèl nesèkmingos lapkričio $21 \mathrm{~d}$. - pirmosios kautynių dienos - turètų prisiimti 2-ojo pèstininkų pulko vadas. Jis, pradèjęs tarnybą Lietuvos kariuomenejje praktiškai nuo pat pradžių, dèl viršytų igaliojimų $1919 \mathrm{~m}$. vasario pabaigoje, konflikto su kariuomenès vadovybe ir atviro „politikavimo“ buvo nušalintas nuo vado pareigu ir areštuotas. Tik pulko karininkų ir kareivių dèka buvo grąžintas ị par-

\footnotetext{
132 Ten pat, p. 216.

${ }^{133}$ Kavaliauskas V. Lietuvos karžygiai, Vyties Kryžiaus kavalieriai, IV tomas, M-Po (1918-1940). Vilnius, 2012, p 326.

${ }^{134}$ Kavaliauskas V. Lietuvos karžygiai, Vyties Kryžiaus kavalieriai, VI tomas, Šim-Ž (1918-1940). Vilnius, 2014, p. 263.

135 Ten pat, p. 225.
} 
eigas $^{136} .1919$ m. kovo mèn. buvo nušalintas už savivaliavimą ir mirties bausmès paskelbimą pulke, o po dviejų ménesių vèl grąžintas ị pareigas ${ }^{137}$. Tokie pulko vado žingsniai rodo, kad jis jautėsi paskirtas ił per žemas pareigas, manė esąs vertas daugiau. Šis aukštesnių pareigų siekis bet kokiomis aplinkybėmis panašus ị elementaraus garbètroškos ambiciją. Jo, kaip pulko vado, atliktų pareigų prastą kokybę liudija jau anksčiau straipsnyje minèta jo persiųsta klaidinga informacija fronto vadui ${ }^{138}$. Lapkričio $14 \mathrm{~d}$., pasibaigus susitarimui su bermontininkais, visi likę ir nesievakavę jų vienetai buvo laikomi neformaliomis ginkluotomis grupuotemis, kurių interesams nebeatstovavo jokia šalis. Pranešu Jums, kad visos sutartys su vokiečiais lapkričio 14 d. pasibaigè. Oficialiai Lietuvoje vokiečiu nebèra ${ }^{139}$, telegramą fronto vadui atsiuntė Lietuvos kariuomenès vadas Liatukas lapkričio $15 \mathrm{~d}$. Tai buvo akivaizdus raginimas ir akstinas fronto vadovybei pradèti kovos veiksmus. Pasinaudodamas šia situacija ir kariuomenès vado telegrama - raginimu, nors ji buvo skirta ne jam, o fronto vadui, bet kurios turini kaip 2-ojo péstininkų pulko vadas greičiausiai žinojo, V. Glovackis nusprendè nedelsiant dar tą pačią lapkričio $15 \mathrm{~d}$. savo iniciatyva pulti bermontininkus. Delsimu kaltintam fronto vadui teko atkalbèti įsikarščiavusi pulko vadą, kad galètų pradèti puolimą visu frontu ${ }^{140}$. Šis pulko vado veiksmas tik padidino įtampą ne tik su fronto vadovybe, bet ir tarp pulko karininkų, kurių dalis, kaip ir dauguma karių, veržèsi i kovą, o kai kurie vadai blaiviau vertino situaciją ir laukẻ nurodymų veikti viso fronto sudètimi. Tai supriešino pulko karininkus tarpusavyje $\mathrm{e}^{141}$. Be to, 2-asis péstininkų pulkas turejo dar vieną ịdomią problemą - nemažai jo karininkų kalbejo rusiškai ir nebendravo su kareiviais lietuviškai ${ }^{142}$.

\footnotetext{
${ }^{136}$ Lietuvos krašto apsaugos ministrai ir kariuomenès vadai, t. 2. Atsakingasis redaktorius ir sudarytojas Surgailis, G. Vilnius, 2008, p. 55.

${ }^{137}$ Rakutis V., Vaičenonis J. Lietuvos didžiojo kunigaikščio Algirdo mechanizuotojo pèstininkų bataliono istorija, p. 88.

138 Jankauskas V. Kario kelias. Generolas Kazimieras Ladiga Nepriklausomybès kovose, p. 169.

13919191115 Generolo Liatuko pranešimas 1-os brigados vadui. LCVA, f. 929, ap. 3, b. $18,1.43$.

${ }^{140}$ Lesčius V. Lietuvos kariuomenè Nepriklausomybės kovose 1918-1920, p. 168.

${ }^{141}$ Petruitis J. Mūsǔ žygiai, p. 163.

${ }^{142}$ Surgailis G. Antrasis Lietuvos didžiojo kunigaikščio Algirdo pėstininkų pulkas, p. 97.
} 
Skaitant „Karo archyvo“ XIII tomą, užkliuvo šiame leidinyje išspausdintuose dviejų autorių straipsniuose visiškai prieštaringos mintys - Alfonsas Eidintas teigia ${ }^{143}$, kad prie Radviliškio mūsų kariuomene panaudojo apeinamųjų manevrų ir tiesioginès atakos derinị, o Aleksandras Baniusevičius rašo, jog 1-ojo bataliono vadas tikejjosi, kad Radviliški pavyks lengvai užimti, todèl puolè tiesiai atvira vietove, nedarydamas didesnių apèjimų manevrų ${ }^{144}$.

Pabrèžtina, kad ịtampa tarp bermontininkų ir lietuvių augo, didejjo kariuomenių koncentracija išilgai fronto. Lapkričio 20 d. vokiečiai pareiške protestą, kad lietuviai juos puldinejja, ypač ties Šiauliais ir Radviliš$\mathrm{kiu}^{145}$. Lietuvių puolimą reikètų laikyti bermontininkams netikètu. Apie tai savo atsiminimuose rašo ir Radviliškio kautynèse dalyvavęs Vokiečiu savanorių rinktinès vadas mjr. C. Brandis, kuris lietuvių puolimą pavadino dūriu ị nugarąą ${ }^{146}$. Tai galejo reikšti, kad bermontininkai daugiausia dèmesio skyrè kitiems klausimams ir problemoms, greičiausiai susijusioms su nesèkmingais kovos veiksmais ir ịvykiais Latvijoje. Kad lietuvių operacija buvo netikèta, rodo ir tai, kad Radviliškio kautynèse nedalyvavo nė vienas bermontininkų šarvuotasis traukinys. Nors praktiškai visą laiką mažiausiai du bermontininkų šarvuotieji traukiniai veike Šiaulių-Radviliškio ruože, buvo naudojami reidams ị Šeduvą, Baisogalą, Linkaičius vykdyti. Vèlgi manytina, kad šie traukiniai galèjo vykti Joniškio, Latvijos link ir lydèti bei dengti po pralaimèjimo atsitraukiančias bermontininkų 1-ojo korpuso pajėgas su pačiu P. Bermontu priešakyje. Galima net daryti atsargią prielaidą, kad traukinių išvykimo faktas buvo žinomas ir lietuviams, nors apie tai niekur neužsimenama. Bet žinant, kad lietuvių Radviliškio puolimas „istrigo“ iš pietryčių pusès, kur stovèjo malūnai ir akmenine tvora aptvertos kapinès, o tarp jų èjo bègiai, belieka ịsivaizduoti, kokių dar iš lietuvių pastangų būtų pareikalavęs šarvuotasis traukinys, iš kurio tarp bermontininkų ir labai tvirtų gynybinių pozicijų būtų paleista galinga ugnis.

\footnotetext{
${ }^{143}$ Eidintas A. Nepriklausomybės kovos. Karo archyvas, t. 13, p. 122.

${ }^{144}$ Baniusevičius A. Lietuvos kariuomenès kautynès su bermontininkais prie Radviliškio. Ten pat, p. 146.

145 Paoletti C. Vokiečių evakuacija iš Lietuvos 1919 m. Italijos tarpsąjunginès komisijos nario akimis: 1919 m. spalis-gruodis. Karo archyvas, t. 27. Vilnius, 2013, p. 99.

146 Čepėnas P. Naujųjų laikų Lietuvos istorija, t. 2, p. 557.
} 


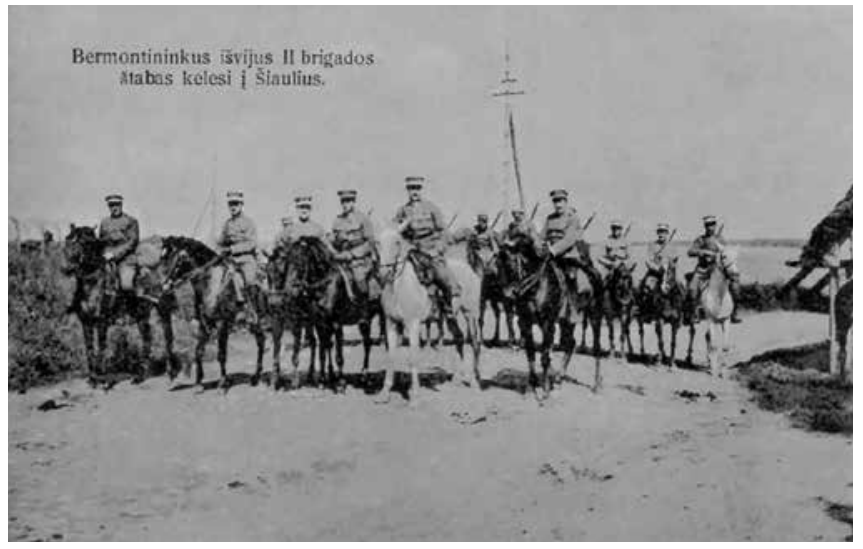

Bermontininkus išvijus fronto štabas keliasi i ̌̌iaulius. Šiauliu „Aušros" muziejus

Apibendrinant galima teigti, kad 2-ojo pėstininkų pulko vadas V. Glovackis buvo nepatyręs ir nekreipdavo dèmesio ị bataliono vadų patarimus, jis akivaizdžiai per daug pasikliovè savimi, buvo nepamatuotai ambicingas, kartais parodydavo nereikalingą ir pavojingą iniciatyvą. Visa tai leidžia daryti prielaidą, kad pasiruošimas Šiaulių-Radviliškio operacijai vyko neįvertinus batalionų galimybių ir priešininko pajėgumų. Jis nesuprato, kad bermontininkai buvo dantimis ir nagais ịsikibę ne ị Šiaulius, o ị Radviliškį, kuris buvo geležinkelio mazgas su keliomis geležinkelio atšakomis ịvairiomis kryptimis. Radviliškị bermontininkai laikè strateginiu ir kartu svarbiu susisiekimo mazgu ${ }^{147}$. Tokiu pat svarbiu ši mazgą laikè ir lietuviai ${ }^{148}$. Dar spalio $16 \mathrm{~d}$. bermontininkai, siekdami sustiprinti Radviliškio apsaugą, iš Rygos fronto perdislokavo C. Brandžio vadovaujamą savanorių rinktinę ${ }^{149}$. O lapkričio $15 \mathrm{~d}$. Lietuvoje liko, be jau minètos C. Brandžio rinktinès ir Geležinès divizijos, G. Rosbacho rinktinės, Vokiečių legiono bei kitų padalinių, kariai, už kurių veiksmus Vokietijos vyriausybė jau nesièmė atsakomybès. Jie, iš viso 19103 bermontininkai, tarp jų - 3830 rusų, susitelkẻ Šiaulių-Radviliškio ruože ${ }^{150}$. O lietuviai pritrau-

\footnotetext{
${ }^{147}$ Lietuvos krašto apsaugos ministrai ir kariuomenės vadai, t. 2, p. 56.

148 Ališauskas K. Lietuvos kariuomenė (Istorinè apžvalga), Karas su bermontininkais. $\mathrm{Ka}$ rys, lapkritis, 1957, p. 284.

149 Čepėnas P. Naujųjų laikų Lietuvos istorija, t. 2, p. 550.

${ }^{150}$ Lesčius V. Lietuvos kariuomenè Nepriklausomybės kovose 1918-1920, p. 200.
} 
ke ị ši fronto barą 2 dalinius - 1-ajji ir 2-ajj pėstininkų pulkus ${ }^{151}$. İdomu ir tai, kad 2-ojo péstininkų pulko vadas V. Glovackis buvo teikiamas apdovanoti už Radviliškio kautynes antruoju Vyčio Kryžiumi (pirmą jau buvo gavęs už pasižymèjimą bolševikų fronte), tačiau jo negavo... Nors turime labai daug pavyzdžių, kai tiek karininkai, tiek puskarininkiai ir kareiviai buvo teikiami apdovanoti antru Vyčio Kryžiumi ir ji gaudavo. Tai yra dar vienas netiesioginis įrodymas ir argumentas, kad 2-ojo péstininkų pulko vadas rengiantis kautynems ir per kautynes savo pareigas atliko prastai. Be to, 2-ojo pesstininkų pulko vadas V. Grigaliūnas neižvelgè savo kaltès, o už nesèkmingą puolimą visą kaltę suvertė 2-ojo péstininkų pulko 1-ojo bataliono vadovybei bei kitų batalionų vadams dèl to, kad tarpusavyje nepalaike ryšio. O kas kitas turèjo organizuoti ir užtikrinti batalionų tarpusavio sąveiką, jei ne pulko vadas? Vadas tiesiog manė, kad mūšyje buvo per daug šaudyta... ${ }^{152}$ Savo individualiais veiksmais ir ketinimais pradeti puolimą pulko sudètyje jis iš dalies paskatino fronto vadą K. Ladigą greičiau pradèti bermontininkų puolimą visu frontu.

\section{APIBENDRINIMAS}

Kovu už Lietuvos nepriklausomybe istorijoje Radviliškio vardas įrašytas aukso raidemis, nes jo paèmimas ir plk. P. Bermondto grupiu nugalejjimas Lietuvos nepriklausomybei turëjo milžiniškos reikšmès. Patys bermontininkai stebejosi Lietuvos kariuomenès narsumu, teigé, jog lietuviai kovojo geriau už kazokus ${ }^{153}$.

Pralaimèję bermontininkai pareiškè, kad lietuviai esą geriau kovojo už kazokus. Viena vertus, jiems reikèjo pasiteisinti, kodèl ir kam pralaimejjo, ir sugretinti su turima patirtimi. Tai greičiausiai buvo pasakyta vokiečių vadų, kurie, matyt, dar Pirmojo pasaulinio karo metu igijo karčios patirties kovose su Rusijos ir Ukrainos kazokais.

\footnotetext{
${ }^{151}$ Ališauskas K. Lietuvos kariuomenė (Istorinè apžvalga), Karas su bermontininkais. Karys, lapkritis, 1957, p. 284.

${ }^{152}$ Lietuvos krašto apsaugos ministrai ir kariuomenès vadai, t. 2, p. 103.

${ }^{153}$ Lesčius V. Lietuvos kariuomenè Nepriklausomybès kovose 1918-1920, p. 227.
} 
Vokiečių savanorių rinktinės vadas mjr. C. Brandis, dalyvavęs Radviliškio kautynèse, savo atsiminimuose reiškia dideli nepasitenkinimą ir daug priekaištų dèl lietuvių kirsto smūgio bermontininkams. Jis teigia, kad bermontininkai laisvinę Lietuvą iš bolševikų, sudarę sąlygas lietuviams organizuoti savo kariuomenę ir valstybę, o lietuviai paskui vokiečių dalinius puolę iš užnugario ${ }^{154}$.

Vokiečių kariuomenè tuo metu buvo laikoma geriausiai ginkluota, parengta ir patyrusia ${ }^{155}$, galima sakyti, karo elitu. Savo atsiminimuose V. Skorupskis rašo: Priešas gynèsi atkakliai su moderniškiausia technika, kuri buvo vartota Didžiojo karo pabaigoje Vakarų Europos kariuomenès, ir su prityrusiais kareiviais, nes visi buvo Didžiojo karo dalyviai ${ }^{156}$. O Lietuvos kariuomenės dauguma karių savanorių, daugiausia ịvairaus amžiaus neturtingi ūkininkai, neturejjo jokios patirties ir apie karybą nusimanė nedaug, stokojo elementarios kariškos disciplinos. Lietuvos kariuomenè sèmèsi patirties kovose su rusų bolševikais Dauguvos fronte. Daugumai tai buvo pirmasis kovos krikštas. Lietuvių supratimą ir menką patirtị liudija jų elgesys su šalmais: lietuviai, susirèmimuose su bolševikais kelis kartus pastebejję, kad pastarieji prastai šaudo ir beveik nepataiko, išmète savo vokiečių gamybos M16 šalmus, nes juos laikè nepatogia, trukdančia kovoti atviruose plotuose ir apskritai nereikalinga apsaugos priemone ${ }^{157}$. Su šalmais likę vieninteliai žemaičiai tapo kitų karių pajuokos objektu. Kiek vèliau tie, kurie kažkada išmètè šalmus, papuolę ì bermontininkų frontą, netrukus suprato, kad vokiečiai yra kur kas geriau parengti, taikliau šaudo ir pataiko. Be to, vokiečiai turejjo milžinišką apkasų karo, kaip buvo vadinamas ir Pirmasis pasaulinis karas, patirtị. Šiame kare kario galvą, iškištą iš apkaso stengiantis ką nors pamatyti, visada turèjo saugoti šalmas, kartais turintis net papildomas apsaugos plokšteles, kurios buvo kabinamos ant M16 šalmų „ragelių“, nuo kurių ir kilo šių šalmų pavadinimas - „raguočiai“. Netrukus bermontininkų fronte lietuviai pradejo vienas iš kito vogti šalmus, todèl jie tapo viena svarbiausių kario ekipuotès dalių, kurią reikèjo akylai saugoti ir nuo saviškių ${ }^{158}$.

\footnotetext{
154 Čepėnas P. Naujųjų laikų Lietuvos istorija, t. 2, p. 557.

${ }^{155}$ Vincas Grigaliūnas-Glovackis. Generolo atsiminimai. II-III dalis, p. 97.

156 Skorupskis V. Per aukas ir pasišventimą laimejome, p. 21.

${ }^{157}$ Pyragius J. Kovosiu, kol gyvas, p. 15.

158 Ten pat, p. 21.
} 
Neįtikètina pergalè, pasiekta kautynèse prie Radviliškio, paimtas karo grobis ir jo vèlesné reikšmé Lietuvos kariuomenès plètrai, karių ir apskritai Lietuvos gyventojų išaugusi motyvacija, tikèjimas savo veiksmų teisètumu ir nepriklausomos Lietuvos, kaip lygiavertès valstybès, perspektyva, pagaliau idètų pastangų, kad tai būtų pasiekta, ir patirtų nuostolių santykis daro ši ịvykị legendiniu. Legendines tampa ne tik kautynès, bet ir visi jose dalyvavę Lietuvos kariuomenès kariai ir vadai, net ir galimai prièmę klaidingus sprendimus. Radviliškio atveju puikiai tinka posakis „Nugalètojų neteisia“. Tai reiškia, kad nugalëję bet ko-

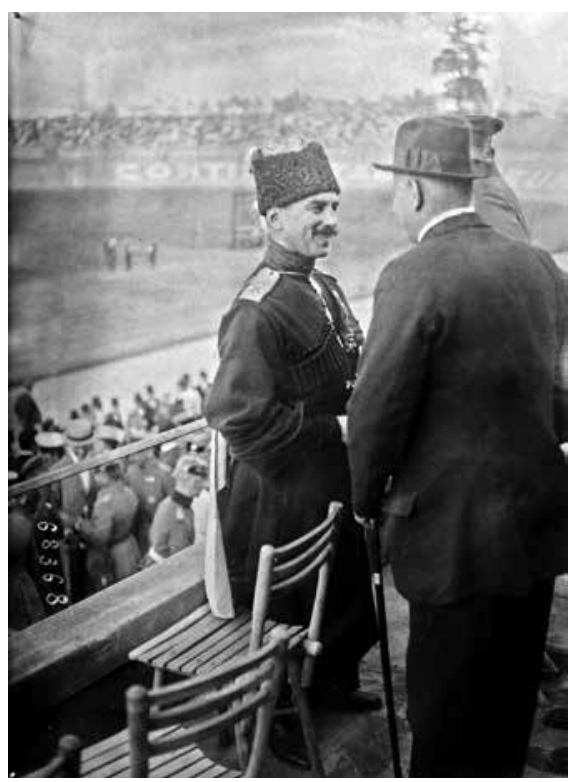

Pavelas Bermontas-Avalovas Berlyne,

Griunvaldo stadione, $1921 \mathrm{~m}$. rugpjūčio $24 \mathrm{~d}$. Prancüzijos archyvas (https://gallica.bnf.fr) kiais, netgi pačiais keisčiausiais ir sunkiai paaiškinamais būdais, retai smerkiami ar teisiami, nes tie, kurie galètu tai padaryti, arba yra nugalèti, arba nedrịsta to padaryti, arba tiesiog bijo nugalètojų stiprybès, jiems nuolaidžiaudami. Kalbama, kad ši fraze priskiriama Rusijos imperatorei Jekaterinai II (rus. Екатерина II Великая), kuri ant prašymo nuteisti garsųji vadą Aleksandrą Suvorovą savo ranka užrašè: „Nugalètojų neteisia.“ Istorikams taip ir nepavyko rasti šio posakio kilmès patvirtinimo. Užtat Romos istoriko, rašytojo ir politikos veikèjo Publijaus Kornelijaus Tacito darbuose pateikiamas kitas jo variantas: „Nugalètojų niekas neprašys pasiaiškinti. “159 Tokia filosofija ir logika vadovaujantis, „legendinès“ Radviliškio kautynès ir nugalètojai igyja amžiną neliečiamumo ir nekvestionavimo imunitetą. Jau ne

${ }^{159}$ Publijaus Kornelijaus Tacito posakiai, http://www.satenai.lt/2014/10/28/apie-sparnuotu-posakiu-kilme-3/ (žr. 2018-10-15) 
kartą minètas vokiečių savanorių rinktinès vadas mjr. C. Brandis savo atsiminimuose ne tik priekaištavo lietuviams dèl netikèto puolimo prie Radviliškio, bet kartu ir kritikavo savo kariuomenės veiksmus ir vadovybès politiką, kuri ir išprovokavo įtampą, pasibaigusią fronto prieš juos sutelkimu ir ginkluotais lietuvių smūgiais įvairiose vietose išilgai fronto. Jis rašo, esą Bermondto daliniai panaikinę Lietuvos valstybès organu veikla daugelyje vietu ir skelbe Rusijos vyriausybès pretenzijas i Lietuvą ${ }^{160}$, ir leidžia suprasti, kad taikaus lietuvių pritarimo tam tikrai negalima buvo tikètis. İdomu ir tai, kad žodis „bermontiada“ tarpukariu buvo tapęs žodžio „avantiūra“ sinonimu. Tarpukario spaudoje galima rasti netgi sąvoką „lenkų bermontiada"161, kuri reiškè tą patị, ką ir lenkų avantiūra. Tarpukariu neretai Liucjanas Želigovskis buvo vadinamas naujuoju P. Bermontu ir lyginami jų veiksmai ${ }^{162,163}$. Bermontininkai ir kovos su jais buvo prisimenama nuolat, o itin dažnai - 1933 m. Adolfui Hitleriui atejus ị valdžią. Per bermontininkų prizmę Lietuvoje dažnai reikštas ir požiūris ị Vokietijos vykdomą politiką - tai buvo tarsi tarpusavio santykių barometras. Šią tendenciją puikiai atspindi tarpukariu Lietuvos šaulių sąjungos žurnalo „Trimitas“ 1021 numeryje išspausdintų publikacijų apie bermontininkus analizè. Vidutiniškai nuo 1920 iki 1940 m. per metus publikuota 8,8 straipsnio šia tema, dažniausiai užsimenant apie juos visų Nepriklausomybès kovų kontekste, greta minint ir kovas su bolševikais bei lenkais. Daugiausia publikacijų - 16 - apie bermontininkus paskelbta 1934 ir 1936 m. A. Hitleriui atejus ị valdžią, ši tema atgaivinta. Be to, P. Bermontas pradejo aktyviau reikštis Vokietijoje. Tai rodo ir 1933 m. „Trimite“ pasirodžiusi žinutè: Hitlerio valdžia Bermontui pavedè organizuoti ir mankštyti baltuosius rusus, emigrantus. Tikimasi iš ju sudaryti 12.000 - visq divizija, kuria bus galima panaudoti ateity, sovietus Rusijoje begriaunant. Kasmet bus priimama po 2000 jaunu rusų ${ }^{164}$. Bet, pavyzdžiui, $1925 \mathrm{~m}$. nebuvo išspausdinta nè vienos publikacijos. Vadinasi, santykiai su Vokietija prijungus Klaipèdą 1923 m. atšilo. 1925 m. su Vokietija buvo pasirašyta sutartis dèl gyventojų optacijos. Klaipėdos

\footnotetext{
160 Čepėnas P. Naujųjų laikų Lietuvos istorija, t. 2, p. 557.

161 Trimitas, 1920, Nr. 12, p. 16.

162 Trimitas, 1933, Nr. 14, p. 261-262.

163 Trimitas, 1920, Nr. 16, p. 2.

164 Trimitas, 1933, Nr. 27, p. 535.
} 
krašto gyventojams suteikta teisè gauti Vokietijos pilietybę ir ten išvykti. Pilietybę pasirinko $10 \%$ gyventojų (apie 13 tūkst. žmonių). Taip pat pažymètina, kad pati bermontininkų idèja po pralaimejjimų Latvijoje ir Lietuvoje neišnyko. Bermontininkai, susibürę $\mathfrak{i}$ karių veteranų judejjimą „Baltikumkampfer“ (liet. „Baltijos kovotojas“), Vokietijoje 1922 m. leido savo laikrašti „Volk und Wehr“ (liet. „Liaudis ir kova“), kuriame grasino Vokietijos valdžiai ir pranašavo, kad jiems dar teks grịžti ị Rytus ruošti kolonijų Vokietijai ${ }^{165}$. Lietuvos nepriklausomybès ịvykius aprašè ir Vakarų šalių spauda. İvykius Lietuvoje interpretuoja lenkų leidinys „Kurjer Polski“ (liet. „Lenkijos kurjeris"), kuriame teigiama, kad vokiečiu karių buvimas Baltijos šalyse yra slaptos Vokietijos politikos regione įrodymas. Maža to, buvo teigiama, kad Lenkijos vyriausybès pareiga - apginti lenkus, esančius Lietuvos teritorijoje ${ }^{166}$. Bermontininkų avantiūrą aprašè ir vieną didžiausių tiražų pasaulyje turintis dienraštis „The New York Times“. Kovos su bermontininkais aptartos 11 straipsnių, kurie laikraštyje išspausdinti 1919 m. vasarą-1920 m. sausio mèn. ${ }^{167}$ Ši tema, palyginti su kitomis temomis - apie kovas su bolševikais ar lenkais, sulaukè mažiausiai dèmesio. Nors, kita vertus, didesnis ar menkesnis dèmesys Vakarų spaudoje jau buvo pripažinimas ir teigiamo ịvaizdžio formavimas, nes Lietuva kovojo su bendru Europos priešu (išskyrus lenkų atveji).

Šio straipsnio pabaigoje būtina pacituoti tuometes Lietuvių nuotaikas puikiai iliustruojantị „Trimite “ išspausdintą kreipimąsi ị šaulius ir visuomenę:

Išmušè garbinga valanda, kada galim eiti mūsų prabočiu pèdomis. Palikim ateinančioms kartoms tą šviesią atmintị, kokią mums senuoliai paliko, kad ir mes mokẻjom savo laisvę apginti. Išsipraktikavę esam kovose su Bermonto gaujomis. Rodès, niekas nebeizveiks tos žmogžudžiu gaujos. O drąsa ir tèvynès meilè viska ịveikè. Isiveržusius dvarponiu legionininkus iš kiekvieno krūmelio ir ravo pasitikim su kulka. Bene prisotinsim ju apetitą! Kiekvienoj bakūžèlèj priešas lai atras tvirtovę, kurioj jis sutiks savo galą. Mes nenorim ju krašto, nenorim nieko vergt, bet ir savo žemę mokam gint.

\footnotetext{
165 Trimitas, 1922, Nr. 13 (84), p. 10.

166 Kurjer Polski, 1919, Nr. 202.

167 Strelcovas S. A. Lietuvos nepriklausomybès karas 19018-1920 The New York times puslapiuose. Karo archyvas, t. 32, p. 41-45.
} 


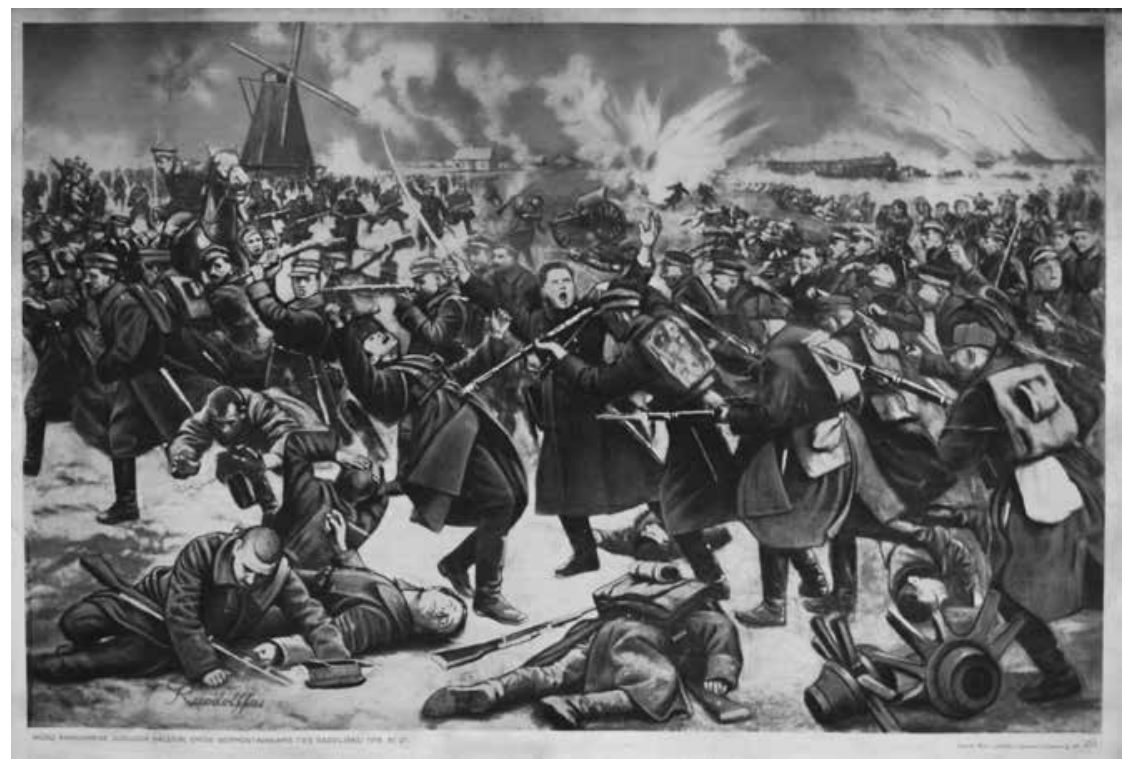

Priešui duokim du keliu: arba ko greičiausiai išsinešdini iš Lietuvos, arba savo kaulais įtręšt ta žemę, kuriq jie per amžius mūsü prakaitu, ašaromis ir krauju tręšé! Vietoj mūsu gardžios duonos lai sutiks išalkęs priešas akmenị! Sukelkim visą kraštą prieš mūsų žudytojus!168

\section{IŠVADOS}

1. Vienas pagrindinių veiksnių, padejjusių Radviliškyje pasiekti pergalę, buvo tinkama Šiaulių-Radviliškio operacijos pradžia. Bermontininkai buvo praktiškai ką tik patyrę pralaimėjimą Latvijoje prie Rygos, kur lapkričio 11 d. juos sumušè Antantès karo laivyno palaikoma Latvijos kariuomenè. Tai buvo laikotarpis, kai bermontininkų vadovybé ir visa kariuomenė buvo sutrikusi. Bermontininkų karių moralè ir kariška disciplina buvo palaikoma tik mažesnių vienetų vadų dèka, bet vieningos bermontininkų kariuomenės nebeliko. Nebelikus vieningos kariuomenès, nebeliko ir ją vienijusių tikslų. Bermontininkai kovėsi ir gynė užim-

168 Trimitas, 1920, Nr. 9, p. 23. 
tas pozicijas prie Radviliškio, nes paprasčiausiai nebeturejjo kitos išeities, kovèsi jau ne dèl kažkieno diktuojamos politikos igyvendinimo regione, o dèl elementariausio išgyvenimo. Jie tiesiog privalejo apginti tiesiausią ir greičiausią atsitraukimo iš Baltijos kraštų ị Prūsiją kelią. Kautynèse nedalyvavo bermontininkų turèti šarvuotieji traukiniai, kurie greičiausiai buvo išsiųsti jų kariuomenès atsitraukimui iš Latvijos pridengti.

2. Dar prieš pralaimèjimą latviams prie Rygos aukščiausioji bermontininkų vadovybè visais įmanomais būdais buvo tarpusavyje susikiršinusi, susipykusi, ir tai turejjo didelę ịtaką žemesniesiems vadams ir karių tarpusavio santykiams. Vokiečių ir rusų vadų ir karių konfliktai buvo tiesiog užprogramuoti nuo pat pradžios bandant sukurti vieningą darinị bermontininkų kariuomenę. Vokiečiai ir rusai Pirmajame pasauliniame kare buvo skirtingų kariavusių pusių atstovai. Dalis rusų iš viso bermontininkų sudètyje atsidūrè automatiškai, nes buvo vokiečių belaisviai. Todèl konstruktyvi sąveika tarpusavyje dèl kažkokių aukštesnių geopolitinių tikslų buvo praktiškai neįmanoma. Atvirkščiai - visą bermontininkų egzistavimo laikotarpi tęsèsi vidaus konfliktai. Dèl to kariuomenè buvo nemotyvuota ir morališkai silpna.

3. Apie Radviliškio kautynes buvo sukurta keletas mitų, vienas jų apie kautynių pradžią, t. y. kad kautynès pradètos be kariuomenės vadovybès žinios. Apie tai, kad vyriausiasis kariuomenės vadas davè ịsakymą pulti bermontininkus, savo atsiminimuose rašo 1-ojo pėstininkų pulko vadas V. Skorupskis. Kad kariuomenès vadovybė Kaune iki smulkmenų žinojo visą kautynių eigą, patvirtina ir fronto vado telegramos, kuriose išdèstyta situacija.

4. Lietuvos kariuomenè pasiekè sunkią pergalę, nors 2-ojo pėstininkų pulko ir jo 1-ojo bataliono vadai padarè daug klaidų. Lietuviai, skirtingai nuo bermontininkų, turèjo tikslą apginti savo šeimas, žemę, savo kraštą. Pažymėtina, kad Šeduvoje dauguma palaidotų 2-ojo pėstininkų pulko karių buvo kilę iš Vilkaviškio krašto. Kariai, kurie puikiai suprato, kad bermontininkai, nors ir toli esantys nuo jų gimtųjų namų, kelia pavojų valstybès egzistencijai, jų šeimoms, todèl buvo pasiryžę priešą sumušti būtent čia, kur jis buvo, prie Radviliškio. Lietuvių kariai, turintys mažai kariavimo patirties, puikiai suvokè saugumo reikšmę ir puoselèjo ịskiepytas vertybes.

5. Lietuvos kariuomenès karininkai ir kariai veržèsi i̇ mūšį. Jų jau praktiškai nebuvo įmanoma sulaikyti ir stabdyti, vyko savavališki ber- 
montininkų užpuolimai ir pavienès žvalgybos iniciatyvos priešo teritorijoje. Bet kada galejo būti savavališkai puolama didesnèmis pajègomis.

6. Lietuvos kariuomenès ir bermontininkų patirti nuostoliai yra neproporcingi - lietuvių gerokai mažesni, kas nepaaiškinama remiantis taktikos meno normomis ir logika, dèl to pergalè prie Radviliškio yra dar ispūdingesnè. Lietuviai, prasčiau ginkluoti ir neturintys daug kariavimo patirties, puolime neteko 27 karių (nukauti), 60 buvo sužeisti, o besiginantys kur kas geriau ginkluoti ir Pirmajame pasauliniame kare dalyvavę bermontininkai - 211 karių (nukauti), 430 buvo sužeisti. Vien tik motyvacijos skirtumu tokị santykị sunku pagrịsti. Vertinant visuose mūšio aprašymuose minimą itin stiprią priešo artilerijos ir kulkosvaidžių ugnị kyla pagrịstų abejonių dèl lietuvių patirtų nuostolių. Neaišku, kokia dalis iš $1919 \mathrm{~m}$. kovose su rusais bolševikais ir bermontininkais žuvusiųjų bendro Lietuvos karių skaičiaus - 530 - yra bermontininkų fronte patirti nuostoliai. Pateiktas nukautų lietuvių, kurių dalis palaidota už Radviliškio rajono ribų, skaičius (27) nesutampa su Radviliškio rajone palaidotų karių, kurių vardinis sąrašas žinomas, skaičiumi (29). Galima daryti prielaidą, kad, siekiant pridengti dèl nekompetencijos nesėkmingą puolimo pradžią, vis dèlto ataskaitose žuvusių lietuvių skaičius galèjo būti sumažintas, o priešininko nuostolių - padidintas. Bermontininkų kapų Šiaulių apskrityje nèra arba jų nerasta. Atsakymų, kiek iš tikrųjų bermontininkai patyrè nuostolių, galima būtų bandyti ieškoti Vokietijos archyvuose.

7. Galima daryti prielaidą, kad Vokietijos konstruktas „bermontininkai“ gimè, kai vokiečiai prarado galimybę dalyvauti kuriant Lietuvos ir Latvijos valstybes.

8. Dèl ypatingų santykių su Vokietija 1917 m. gruodžio 17 d. deklaracija turèjo ịtakos, kad susiklostè ypatingi santykiai ir su bermontininkais. Latviai ir lenkai lietuvius laikè provokiškais, o 1919 m. spalio $30 \mathrm{~d}$. lietuvių susitarimą su bermontininkais - tikra išdavyste. Kautynėmis su bermontininkais lietuviai provokiškumą iš dalies paneigè.

9. Tiek lietuvių, tiek latvių pergalès prieš bermontininkus iš dalies padejo Sovietų Rusijai, kuri, Baltijos valstybėms patyrus nesėkmę, anksčiau ar vèliau būtų turèjusi pati spręsti kaimynystèje bandžiusių ịsikurti bermontininkų - Vakarų savanorių armijos - baltagvardiečių klausimą. Bermontininkai atvirai deklaravo antibolševikines nuotaikas, tad, jiems tebeegzistuojant pašonėje, Rusijos pilietinio karo pabaiga buvo neịmano- 
Kretinga. - Šventẻ pirmojo bataliono, antro pulko, Kretingoje gruodžio mèn. 21 d. $1919 \mathrm{~m}$.

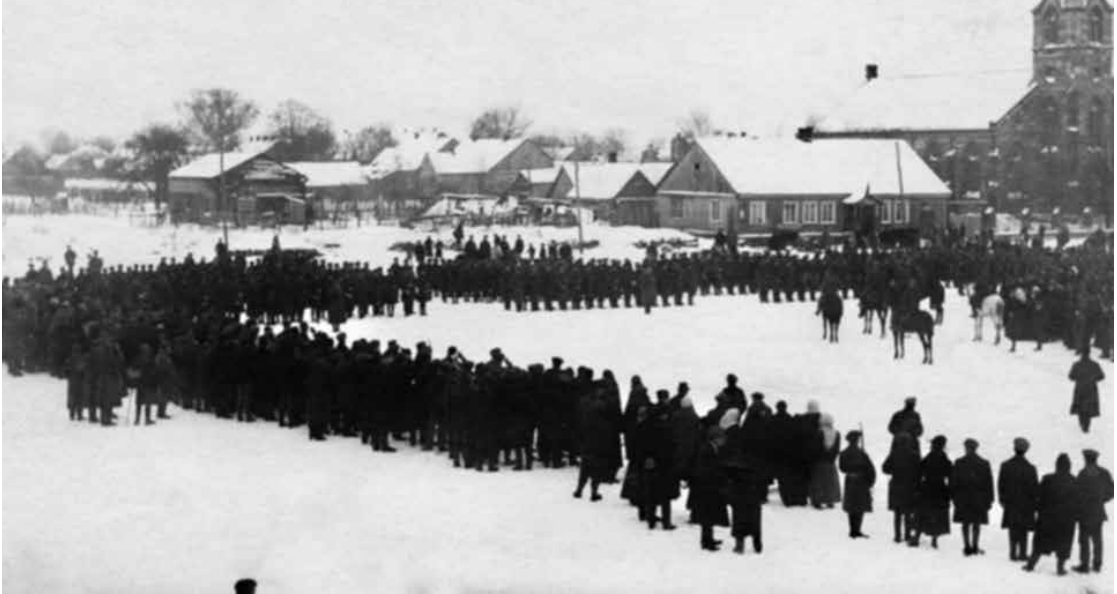

Tik išvijus bermontininkus - Lietuvos kariuomenès 2-ojo pėstininkų pulko 1-ojo bataliono šventè 1919-12-21 Kretingoje. Kretingos muziejus

ma. Galima tik spèti, ar Sovietų Rusija šị klausimą būtų sprendusi koaliciškai su Baltijos valstybėmis, ar tai būtų buvusi bolševikų pavienė kova ir kartu revanšas lietuviams ir latviams už skambius pralaimèjimus jiems Dauguvos fronte.

Pirmasis pasaulinis, arba Didysis, karas baigèsi 1918 m. lapkričio 11 d., taikos sutartis buvo pasirašyta 1919 m. birželio 28 d. Per ketverius metus igavęs pagreitị, jis buvo sunkiai sustabdomas. Nors oficialiai buvo nutraukta ugnis ir pasirašyta taikos sutartis, karo veiksmai tebevyko. Nepriklausomybės karas ir kovos su bermontininkais buvo viena iš Lietuvoje dar nesibaigusio Didžiojo karo formų. Lietuvos kariuomenè prie Radviliškio sukūrè stebuklą, kurị, tinkamai pasirengus, reikètų išnaudoti puoselejjant ir ugdant Lietuvos gyventojų pilietiškumą, skiepijant jaunimui vertybes, toliau pasaulio bendruomenès akyse kuriant lietuvių, tautos, turinčios tikro kovotojo geną, ivvaizdị. 


\section{ŠALTINIŲ IR LITERATŪROS SĄRAŠAS}

\section{Archyviniai dokumentai}

Lietuvos centrinis valstybès archyvas (LCVA): f. 929, Kariuomenès štabas.

Lietuvos valstybės istorinis archyvas (LVIA): f. 1120, Šeduvos Romos Katalikų bažnyčia, f. 1529, Radviliškio Romos Katalikų bažnyčia.

\section{Atsiminimai}

Bermondt-Avalov P. Im Kampf gegen den Bolschewismus. Hamburg, 1925.

Landsbergis-Žemkalnis V. Iš atminties ekrano. Vilnius, 2009.

Šilietis J. Vokiečių okupacija Lietuvoje 1915-1919 m. paveikslèliuose ir trumpuose jų aprašymuose. Šiauliai, 1999.

\section{Literatūra}

Акунов В. Фрайкоры. Повесть о германских добровольцах. Москва, 2004.

Ališauskas K. Lietuvos kariuomenè (istorinè apžvalga), karas su bermontininkais. Karys, 1957, lapkritis.

Anušauskas A. Lietuvos žvalgyba 1918-1940. Vilnius, 2014.

Laurinavičius Č. Sovietų Rusija suka link taikos politikos. Lietuvos istorija. Nepriklausomybe் (1918-1940), t. X, I d., Vilnius, 2013.

Baniusevičius A. Lietuvos kariuomenès kautynès su bermontininkais prie Radviliškio. Karo archyvas, t. XIII, Vilnius, 1992.

Birontas A. Bermontininkams Lietuvą užpuolus. Kaunas, 1934.

Cyganov J. Rusijos Vakarų savanorių armijos formavimas (1919 m. vasara-ruduo). Baltfort, Nr. 1, Ryga, 2007.

Čapenka A. 2-ojo Vakarų savanorių korpuso formavimo istorija ir jo dalyvavimas „Bermontiadoje“ Lietuvos teritorijoje 1919 metais. Karo archyvas, t. XXV, Vilnius, 2010.

Čepènas P. Naujųų laikų Lietuvos istorija, t. II, Vilnius, 1986. 
Eidintas A. Nepriklausomybės kovos. Karo archyvas, t. XIII, Vilnius, 1992.

Gimžauskas E. Vokiečių karinès okupacijos poveikis Lietuvos visuomenei ir besiformuojančiam valstybingumui 1915-1919 m. Karo archyvas, t. XXV, Vilnius, 2010.

Yčas M. Bermonto dienų atsiminimų žiupsnelis. Mūsų žinynas, Nr. 2, Kaunas, 1921.

Jakobsonas M. Radviliškyje 1918-19 m. Karo archyvas, t. IX, Kaunas, 1935.

Jankauskas V. Kario kelias. Generolas Kazimieras Ladiga Nepriklausomybès kovose. Vilnius, 2004.

Jokubauskas V. „Mažujų kariuomeniu“" galia ir paramilitarizmas. Tarpukario Lietuvos atvejis. Klaipeda, 2014.

Jokubauskas V., Vaičenonis J., Vareikis V., Vitkus H. Valia priešintis. Paramilitarizmas ir Lietuvos karinio saugumo problemos. Kolektyvinè monografija. Sud. H. Vitkus, V. Vareikis. Klaipeda, 2015.

Jurgela R. History of the Lithuanian Nation, Constantine, Cultural Institute. Niujorkas, 1948.

Karo technikos dalių dvidešimtmetis, 1919-1939. Kaunas, 1939.

Laurinavičius Č. Bermontininkai. 1920 m. pradžia. Taika ar karas? Lietuvos istorija, t. X, I d. Nepriklausomybe (1918-1940 m.). Vilnius, 2014.

Lesčius V. Lietuvos kariuomenė Nepriklausomybès kovose 19181920. Vilnius, 2004.

Liekis A. Lietuvos šaulių sąjungos istorija. Vilnius, 1992.

Lukšas A. Laisvės istorijos mozaika. Vilnius, 2017.

Miknys R. Mykolas Römeris. Dienoraštis: 1919 m. birželio 21-oji 1920 m. kovo 15-oji. Vilnius, 2009.

Tamošiūnienè M. Tarp politinio ịrankio ir aukos: karo belaisviai Lietuvos Respublikos politikoje 1919-1923 m. Vilnius, 2014.

Niessel'is A. Vokiečiu išsikraustymas iš Baltijos kraštų. Kaunas, 1938.

Paoletti C. Vokiečių evakuacija iš Lietuvos 1919 m. Italijos tarpsąjunginès komisijos nario akimis: 1919 m. spalis-gruodis. Karo archyvas, t. XXVII, Vilnius, 2013.

Petruitis J. Mūsų žygiai, atsiminimai iš kovų su bolševikais ir bermontininkais. Kaunas, 1935.

Ruseckas P. Savanorių žygiai. Nepriklausomybès karų atsiminimai, 
t. 1, 2. Vilnius, 1991.

Ruseckas P. Lietuvos kariuomenè. Kaunas, 1929.

Skorupskis V. Karas už Lietuvos laisvę. Kaunas, 1934.

Statkus V. Lietuvos ginkluotosios pajègos 1918-1940 m. Chicago, 1986.

Steponaitis V. Bermontininkai Lietuvoje. Mūsų žinynas, Nr. 1 ir Nr. 2, Kaunas, 1921.

Strelcovas S. A. Lietuvos nepriklausomybės karas 1918-1920 m. The New York times puslapiuose. Karo archyvas, t. XXXII, Vilnius, 2017.

Surgailis G. Pirmasis pėstininkų Didžiojo Lietuvos kunigaikščio Gedimino pulkas. Vilnius, 2011.

Surgailis G. Antrasis Lietuvos didžiojo kunigaikščio Algirdo pėstininkų pulkas. Vilnius, 2014.

Vincas Grigaliūnas-Glovackis. Generolo atsiminimai. II-III d. Atsakingas redaktorius Surgailis G. Vilnius, 2017.

Tsyganovs J. The Formation of the West Russian Voluntary Army (summer-autumn of 1919), Nr. 1, Baltfort, 2007.

Valūnas P. Dèl Tèvynès. Kaunas, 1938.

Lietuvos karai. Vilnius, 2014.

Zabulionis N. 1-o pèst. pulko 7 kuopos veiksmai prieš bermontininkus. Karo archyvas, t. X, Kaunas, 1938.

Žymiausi Lietuvos mūšiai ir karinès operacijos. Vilnius, 2013.

Iteikta $2018 \mathrm{~m}$. spalio $15 \mathrm{~d}$. 


\title{
THE LEGENDARY BATTLE OF RADVILIŠKIS
}

\author{
Alvydas TAMOŠIŪNAS \\ Klaipeda University
}

The material for this article have been collected for more than a decennial. A huge amount of books, periodicals and documents kept by the Lithuanian Central State Archives was investigated. The study of the battle place in Radviliškis was done too. The collected materials were used for the lectures. In 2018, the topic was addressed during the young researchers' conference dedicated to the centenary of the restoration of the Lithuanian statehood on April 19 at Šiauliai University and the international conference on history dedicated to the centenary of the Lithuanian Armed Forces on February 19 at General Jonas Žemaitis Military Academy of Lithuania. The article is based on the discourse from the two lectures analyzing the casualties of the conflicting sides. Even though the fights against the Bermontians were widely investigated by the Lithuanian historiography, the researchers neither deepened their knowledge in the number of casualties given by commanders, nor compared them with the enemies' casualties, nor evaluated the fighting sides' potential in defence and offence. In the case of the Battle of Radviliškis, the classic military proportion 1 in defence against 3 in offence was simply inapplicable, however, the victory was achieved. The article provides the reasons and main circumstances that helped to defeat the Bermontians. It is noteworthy that the article does not analyze the battle itself, it estimates the overall context, statistics and considerations. A comprehensive analysis of the battle was done by historian Vytautas Lesčius ${ }^{2}$. The Lithuanian Armed Forces made a miracle in Radviliškis by defeating a well-experienced and equipped enemy in the First World War. The heavily-achieved victory boosted the Lithuanian servicemen's motivation, huge spoils of war were moved towards Kaunas and, consequently, now the Lithuanian society has an independent state capable of defending itself and its citizens.

2 Lesčius V. Lietuvos kariuomenè Nepriklausomybès kovose 1918-1920. Vilnius, 2004. 